Article

\title{
Circular Project Selection: How Companies Can Evaluate Circular Innovation Projects
}

\author{
Anja Eisenreich ${ }^{1, *}$, Johann Füller ${ }^{1}$ and Martin Stuchtey ${ }^{2}$ \\ 1 Department of Strategic Management, Marketing and Tourism, University of Innsbruck, Universitätsstr. 15, \\ 6020 Innsbruck, Austria; Johann.Fueller@uibk.ac.at \\ 2 Department of Geography, University of Innsbruck, Universitätsstr. 15, 6020 Innsbruck, Austria; \\ Martin.Stuchtey@uibk.ac.at \\ * Correspondence: eisenreich.anja@gmx.net
}

Citation: Eisenreich, A.; Füller, J.; Stuchtey, M. Circular Project Selection: How Companies Can Evaluate Circular Innovation Projects. Sustainability 2021, 13, 12407. https:// doi.org/10.3390/su132212407

Academic Editor: Adriana Del Borghi

Received: 1 October 2021

Accepted: 28 October 2021

Published: 10 November 2021

Publisher's Note: MDPI stays neutral with regard to jurisdictional claims in published maps and institutional affiliations.

Copyright: (c) 2021 by the authors. Licensee MDPI, Basel, Switzerland. This article is an open access article distributed under the terms and conditions of the Creative Commons Attribution (CC BY) license (https:/ / creativecommons.org/licenses/by/ $4.0 /)$.

\begin{abstract}
For a transition toward the circular economy (CE) at the firm level, circular innovations are an essential requirement. Many companies are still hesitant to introduce circular solutions, as their future success chances are difficult to predict. Circular solutions often imply a high uncertainty and complexity because they are designed over multiple life cycles and are strongly interconnected with diverse stakeholders. Therefore, an effective selection process tailored to circular innovation is of great advantage. This study examines circular project selection by investigating selection processes and evaluation criteria for circular innovation management. A qualitative research design was chosen, including 18 in-depth interviews with CE experts and representatives from CE pioneer companies. Findings on the selection process show that circular innovation projects are often embedded in a strategic CE framework decision. Whereas idea generation is usually approached bottom-up involving different stakeholders, project evaluation is rather performed top-down by top management or in cross-functional teams. Furthermore, the study discusses evaluation criteria and their CE implications in detail and structures them into a criteria framework that can be used in multi-criteria decision models. This paper makes a theoretical contribution by connecting innovation and CE literature and by providing new knowledge on the still scarcely explored topic of circular project selection. As practical contribution, the study guides managers on how to approach project selection in circular innovation management and thus supports their development toward a CE.
\end{abstract}

Keywords: circular economy; project selection; idea selection; circular innovation; multi-criteria decision making

\section{Introduction}

"Transition from our current resource intensive economic growth model to a resource efficient growth model, to a circular economy (CE), is not only absolutely necessary; it is actually inevitable for all our economies." [1]

The sustainability concept CE that Janez Potočnik, former EU Commissioner for the Environment, refers to is gaining momentum, both in business and in academic research. Our current economic system is based on a linear approach that depends on heavy consumption of natural resources to enable growth [2]. However, in the future, the limited availability of raw materials will combine with a rapidly growing world population $[2,3]$. This development jeopardizes the success of our economy in the long run $[4,5]$. It also threatens our well-being, because more and more waste is created and increasingly pollutes the environment [6]. As our current linear system cannot solve these problems, a new economic model of circular thinking will be necessary $[2,6]$. The $\mathrm{CE}$ is a regenerative industrial economy that aims at decoupling growth from the consumption of resources [6,7]. It is usually regarded as part of the field sustainability as it has the potential to achieve an environmental, economic, and social win for our society [8]. To obtain circularity, a circular 
design should be implemented throughout all stages of material life cycles [9]. Circular solutions range from closed cycle solutions with biological and technical material cycles to systemic solutions such as product-service systems (PSS) or connected mobility $[6,10]$.

For the transition toward a CE at the firm level, circular innovation is a crucial prerequisite [6] to manage in a structured and guided innovation process [11,12]. An innovation process generates product or service ideas, assesses their potential, and decides which innovation projects should go to market launch [13]. Project selection decisions represent an important success factor in innovation management [14] and relate to the context of organizational decision making [15]. In the context of circular innovation, project selection can be especially challenging. First, the success of circular solutions is difficult to predict, as they are usually spread over multiple life cycles and often aim for strategic long-term effects rather than for financial short-term impact $[6,7,16,17]$. Second, circular solutions are integrated in a complex system of different stakeholders that influences their success chances $[18,19]$. Third, a linear mindset and lack of support from employees, middle, and top management can deter the implementation of circular innovations [16,18,20,21]. Therefore, it is crucial for companies to establish an effective project selection process that involves the right decision makers and enables a valid evaluation of circular innovations.

Project selection in innovation management is usually based on criteria [14,22], an approach premised on the notion of goal-based decision making $[23,24]$. The innovation literature suggests a variety of evaluation criteria for project selection, including product characteristics, financial performance, and strategy, but does not provide a uniform metric scheme [22,25]. Literature on evaluation criteria for circular project selection is scarce. Bertoni [26] investigates criteria for a specific case of early design of PSS in a case study, and Alamerew et al. [27] derive criteria for circular product strategies from literature. Both studies set the main focus on developing a multi-criteria decision model and, thus, do not discuss evaluation criteria and their CE implications in detail. Other authors propose criteria to evaluate the circularity of circular solutions, however, with a technical or environmental rather than a business focus e.g., $[28,29]$. To contribute to the research direction of circular project selection from an innovation perspective and provide detailed insights on evaluation criteria that can be applied in multi-criteria decision models, further research is needed. Given the uncertainty of forecasts and the complexity of influencing factors for circular innovations, deeper knowledge on criteria evaluating the future business potential of circular innovations is highly valuable. Therefore, the following research question is examined:

RQ 1: Which criteria do CE pioneer companies regard as relevant for the evaluation of circular innovation projects?

How evaluation criteria are applied and by whom the evaluation of innovation projects is performed varies widely. Options range from bottom-up approaches involving crowds in open evaluation [30] to top-down evaluations with decision makers such as top management [31]. Which approaches and processes are suitable for circular project selection has not been researched up to now. However, the high significance of diverse stakeholders for circular innovation implies that evaluators for project selection have to be chosen carefully. Circular innovation projects should not be held back by a lack of commitment from top management; however, a bottom-up approach might increase the support of internal and external stakeholders. To gain a deeper understanding of the evaluation process, the application of evaluation criteria, and relevant stakeholders for circular project selection, the following research question is investigated:

RQ 2: How do CE pioneer companies evaluate circular innovations and which stakeholders are involved?

To answer the two research questions, a qualitative interview study was conducted with $18 \mathrm{CE}$ experts and representatives from CE pioneer companies that have introduced game-changing or especially elaborated circular solutions. The findings examine the context, process, and stakeholders for circular project selection. Additionally, they identify relevant evaluation criteria with CE-specific implications and structure them into a com- 
prehensive framework. The study makes a theoretical contribution by connecting the CE literature to innovation research and by deepening the understanding of circular project selection. It supports companies on their way toward a CE by providing them with insights from CE pioneer companies and by developing a criteria framework that can be used as a master list for the evaluation of circular innovations. The next sections are structured as follows: Section 2 describes the theoretical background of the study. Section 3 is concerned with research design and methods. Section 4 presents empirical results, which are discussed in Section 5. Section 6 entails final conclusions of the research project.

\section{Theoretical Background}

The theoretical background of this study relates to the concept of a circular economy and to organizational decision making in circular innovation management that will be described in the following.

\subsection{The Concept of a Circular Economy}

The origins of the CE go back to the idea of circular material flows [32] that was further conceptualized by Pearce and Turner [33]. The concept of a CE is related to various schools of thought [8,34], including industrial ecology [35], regenerative design [36], performance economy [37], biomimicry [38], blue economy [39], and cradle-to-cradle design [40]. Although there is no consensus definition of the CE, many authors base their research on the CE understanding of the Ellen MacArthur Foundation [41,42] that regards the $\mathrm{CE}$ as "an economy that is restorative and regenerative by design and aims to keep products, components, and materials at their highest utility and value at all times" [7] (p. 46). The scope of the CE concept is discussed controversially in literature. Some authors take a narrow view of the $C E$ focusing on the $3 R$ framework (reduction, reuse, recycling) $[5,43,44]$. Others regard this view as too narrow and emphasize the importance to implement circularity throughout material life cycles including product development and customer relationship management [9]. Geisendorf and Pietrulla [9] acknowledge the importance of products as a service as part of a circular design but do not include them in the core definition of a CE. In contrast, other authors see PSS as integral part of a CE [10].

This paper takes a broad understanding of the CE and distinguishes two types of circular solutions: closed cycle solutions with biological and technical material cycles and systemic solutions, including PSS and larger systemic solutions $[6,7,10]$. Biological material cycles result from techniques such as anaerobic digestion, whereas technical material cycles are generated, for example, by reuse, remanufacturing, or recycling [6]. PSS consist of concepts such as leasing, product sharing, and pay-per-service models $[10,45,46]$. The most prominent example of larger systemic solutions is connected mobility, which describes multi-modal solutions with different forms of transportation, including sharing, automation, and electricity [7]. The boundaries between closed cycle and systemic solutions are fluid; however, the distinction is useful because it outlines two different CE approaches that are often separately discussed in literature [10].

The opportunities and challenges of a CE at the micro level are mainly discussed in the context of drivers and barriers, distinguishing external and internal influencing factors. External factors such as legislation, financial support, customer attitude, and public awareness can be drivers or barriers, depending on whether they are in favor of a circular or linear economy [18,20,47-52]. Major technological problems and the continuation of low resource prices might discourage companies from introducing circular innovations $[6,50,53]$. However, once resource prices and resource volatility begin to rise and technological progress makes new opportunities available, the transition toward a CE will be fueled $[6,47,49]$.

Internal barriers for a CE include poor leadership, a lack of top-management support, and an oppositional corporate culture, mindset, and incentive system [18,20,50,54]. Furthermore, companies have often set a strong focus on linear business models and fear the uncertain returns of circular solutions $[41,50,55]$. Internal drivers can be a strategic CE 
agenda [21], the reduction of operating costs, new growth opportunities, and competitive advantages $[21,47,49,52,56]$. Closed cycle solutions usually require substantial investments in $R \& D$ but can reduce resource and environmental costs $[5-7,57]$. PSS face barriers such as the need for disruptive change within the company or problems with customer acceptance because clients must relinquish ownership over products $[46,58]$. The CE literature does not agree on specific key drivers and barriers. However, some authors attach particular importance to drivers such as legislation, resource scarcity, or strategy and to barriers such as technology restraints, high investment costs, lack of consumer acceptance, or hesitant corporate culture $[20,21,47]$.

\subsection{Decision Making in Innovation Management}

For a transition toward the CE at the firm level circular product and service innovations are an essential requirement [6]. Within a circular innovation process, companies must select certain promising projects and reject others. These selection decisions are forms of organizational decision making that can be explained based on two theoretical lenses. Attention-based view [15] regards decision making as a result of the decision maker's limited attentional capacity and of structural influences. One form of structural influence are players such as top management, who have an impact on the decision maker's behavior through their power, control, or social influence $[15,59,60]$. In circular innovation management, evaluation approaches and decision processes are influenced by the power of different internal stakeholders who can guide decision outcomes to favor circular innovations or not $[18,21]$. The second theoretical perspective is the notion of goal-based decision making embedded in behavioral theory of the firm $[23,24]$. The notion refers to the assumption that the information required for rational decisions is often not fully available such that decision strategies are needed. These strategies are based on multiple organizational goals that can be used as evaluation criteria and must be satisfied by the selected solution $[23,24]$. To increase decision quality a master list with potentially relevant criteria can be used to avoid that important criteria are overlooked [61]. The notion of goal-based decision making establishes the need for evaluation criteria that serve as important basis for project selection in innovation management [13].

Project selection decisions within the innovation process are usually based on a set of criteria the innovation project must fulfill [13]. The evaluation of projects along these criteria is frequently performed with a top-down approach [62]. Cooper [31] developed the following propositions for top-down evaluations: gatekeepers should be senior managers in charge of project resources. The number of gatekeepers should be limited and should include only key managers who are not simultaneously project leaders. The smaller the project is, the lower the management level can be for the evaluation. For major projects, a cross-functional group of senior managers, for example from R\&D, marketing, operations, and finance, is recommended to obtain a high decision quality. Risks of topdown approaches are a lack of transparency and a possible preference of top managers' "pet projects" [31] (p. 219). Other authors confirm the importance of cross-functional perspectives for project selection as single evaluators, for example in R\&D, might be overconfident regarding an innovation project or oversimplify the evaluation [63-65]. Therefore, different organizational levels should be integrated, or group decisions should be taken $[63,64]$. Partly, the involvement of external stakeholders such as customers, suppliers, consultants, or academics is proposed for an external expert evaluation of the project or for a direct external project selection $[63,64]$.

The latter suggestions do not describe a strict top-down evaluation but combine topdown and bottom-up elements. The probably strongest form of bottom-up evaluation is the approach of open evaluation, a "community-based idea evaluation" [66] (p. 502) that uses the wisdom of a crowd, often an employee or consumer crowd, to evaluate ideas [30,67]. The evaluation can be performed as an absolute judgment that assigns absolute scores to individual ideas, or as relative judgment that compares different alternatives [30,68]. Treatment of whether top-down or bottom-up evaluations are more appropriate for idea 
selection, is inconsistent in the literature. However, authors tend to report a negative impact of top-down approaches on idea generation but regard hierarchy as rather beneficial for idea selection $[69,70]$.

An important success factor for project selection is the definition of suitable evaluation criteria [13]. The number and choice of criteria depend on the evaluation context and on the corporate goals [22,31]. In bottom-up approaches such as innovation contests that produce many ideas, not more than five criteria are usually used for the evaluation [67]. In contrast, top-down approaches allow for more criteria [66], for example when scorecards with 20-25 criteria are applied [31,71]. The number of evaluated ideas also influences the level of detail for the assessment that must additionally correspond with context, type of criterion, and available information $[22,72,73]$. Whereas criteria such as strategy are often assessed only roughly, other metrics, such as profitability, are calculated more precisely [22]. Data and information for the evaluation can come from internal or external sources. Examples include internal information on technology and administration, external data collection from experts, prediction markets, real-market tests, crowdfunding, or ad campaigns [72,74].

Various academic studies have investigated sets of evaluation criteria that have proven relevant in practice. As the choice of criteria depends strongly on the context of the project, the literature does not provide a unified measurement scheme at the level of individual evaluation criteria [22,31]. In contrast, at the level of criteria groups that cluster individual criteria with a similar focus, significant parallels can be identified between different studies. However, as the boundaries between criteria groups are fluid, the specific allocation of criteria differs. Frequently, authors determine the following criteria groups for the evaluation of innovation projects: product, financial performance, strategy, and organization, partly also network and environment [22,25,75].

Product-related criteria often include USP, innovativeness, quality, and product life $[25,75,76]$. Some studies suggest NUF (novel, useful, feasible) frameworks $[77,78]$ to evaluate product features, especially in the early stages of innovation. Financial performance usually refers to profitability and revenue metrics $[22,25,76]$. Some authors focus mostly on profitability measures such as return on investment [25], while others are oriented to market measures, including market potential and market share [75]. Customer-related criteria can be included in the market perspective or set in a separate criteria group to emphasize their particular importance [79]. Strategy is concerned mainly with strategic orientation and strategic fit but can also encompass synergy effects [22,75,76]. Organization-related criteria comprise culture, organizational structure, resource allocation, and knowledge [22,75]. Some studies additionally attach importance to a company's collaboration with its external network, as well as to its legal and economic environment [22,79].

Only few authors have introduced a further hierarchical level clustering criteria groups into dimensions. Dziallas and Blind [22] differentiate between a company-specific dimension, including criteria groups such as strategy, culture, knowledge, or financial performance, and a contextual dimension, referring to the market, network, and environment. However, the two dimensions overlap considerably, in the case of, for instance, market share that belongs to the external criteria group market and, at the same time, is part of companyspecific profitability calculations. Other options to structure criteria groups have been suggested in the literature on portfolio management for new products. Cooper et al. [80] distinguish the dimensions risk vs. reward, financial attractiveness vs. market/concept attractiveness, and market/concept attractiveness vs. ease of implementation. The latter contrasts criteria that influence a product's market success and criteria that are needed to successfully bring the product to the market.

\subsection{Evaluation Criteria in Circular Innovation Management}

Evaluation criteria for circular innovation have not yet been investigated in the literature. However, some important aspects for the evaluation of circular innovations can be derived from $C E$ literature on drivers and barriers as well as advantages and disadvantages 
of circular solutions (see Section 2.1). Potentially relevant criteria for circular project selection might also be found in the wider field of environmental innovation that has strong overlaps with the $\mathrm{CE}$ as it aims at decreasing environmental impacts and at improving the responsible and efficient usage of resources [81]. However, existing environmental innovation research does not investigate criteria for the evaluation of environmental innovation projects. Fichter and Clausen [82] identify drivers and barriers for the diffusion of environmental innovation, such as market power of established suppliers, compatibility with routines, and the influence of pioneers. Other studies reveal further influencing factors such as pricing, cost savings, the support of industry trade associations, the need for behavior modification, compliance with regulations, and technological improvements [81,83,84]. These factors might play a role for the success chances of environmental innovations, but they cannot be equated with evaluation criteria for project selection in a company's innovation process because they reflect the descriptive observation of a diffusion development rather than the prescriptive usage of evaluation criteria.

As in circular and environmental innovation literature no explicit research on project selection criteria can be found, a list of potentially important criteria for circular project selection was based on well-established evaluation criteria in general innovation literature. These general criteria were supplemented with insights from CE research regarding drivers and barriers as well as advantages and disadvantages of circular solutions as far as they contained aspects influencing the future success of circular innovations. The criteria derived from innovation and CE literature were discussed among the co-authors and in an informal interview with a strategy expert (partner at a large strategy consulting firm with cross-industry innovation experience) regarding their importance for circular project selection from a practice-oriented perspective. Based on these discussions, a set of potentially CE-relevant evaluation criteria was developed and thematically sorted (Table 1). These criteria were used in the interview study to stimulate considerations.

Table 1. Evaluation criteria for circular innovation (literature- and expert-based).

\begin{tabular}{|c|c|c|}
\hline Criterion & Examples & Sources (Example) \\
\hline \multicolumn{3}{|l|}{ Cost-related criteria } \\
\hline Operating costs & $\begin{array}{l}\mathrm{R} \& \mathrm{D} / \text { technology, materials, energy, } \\
\text { distribution, disposal, marketing }\end{array}$ & $\begin{array}{l}\text { Alamerew et al. [27], Ellen MacArthur } \\
\text { Foundation [6,7], Evanschitzky et al. [75], } \\
\text { Ghisellini et al. [5], Govindan and } \\
\text { Hasanagic [18], Manzini and Vezzoli [85], } \\
\text { Masi et al. [51], Mont et al. [86], Tura et al. [49], } \\
\text { Yang and Evans [87] }\end{array}$ \\
\hline Investment costs & R\&D & $\begin{array}{l}\text { Ellen MacArthur Foundation [7], Masi et al. [51], } \\
\text { Ronkainen [88], Tukker [46], Tura et al. [49] }\end{array}$ \\
\hline Financing costs/payback period & & $\begin{array}{l}\text { Carbonell-Foulquié et al. [89], Cooper et al. [71], } \\
\text { Griffin and Page [90], Hart et al. [25], Linder and } \\
\text { Williander [91], Tukker [46] }\end{array}$ \\
\hline Special cost effects & $\begin{array}{l}\text { Subsidies, environmental taxes, } \\
\text { externalities such as damages } \\
\text { to health }\end{array}$ & $\begin{array}{l}\text { Alamerew et al. [27], Bertoni [26], Ellen } \\
\text { MacArthur Foundation [6,7], Ghisellini et al. [5] }\end{array}$ \\
\hline \multicolumn{3}{|l|}{ Revenue-related criteria } \\
\hline Market volume/market growth & & $\begin{array}{l}\text { Cooper and de Brentani [76], } \\
\text { Evanschitzky et al. [75], Hart et al. [25], } \\
\text { Martinsuo and Poskela [92], Rochford [93], } \\
\text { Ronkainen [88] }\end{array}$ \\
\hline Sales potential/market share & & $\begin{array}{l}\text { Carbonell-Foulquié et al. [89], } \\
\text { Dziallas and Blind [22], Hart et al. [25] }\end{array}$ \\
\hline
\end{tabular}


Table 1. Cont.

\begin{tabular}{|c|c|c|}
\hline Criterion & Examples & Sources (Example) \\
\hline Pricing/willingness to pay & & $\begin{array}{l}\text { Bruhn and Hadwich [79], } \\
\text { Evanschitzky et al. [75], Singhal et al. [94], } \\
\text { Tukker [46], van Weelden et al. [95] }\end{array}$ \\
\hline Revenue effects on other products & Cannibalization, cross-selling & $\begin{array}{l}\text { Bruhn and Hadwich [79], Cooper et al. [71], } \\
\text { Ellen MacArthur Foundation [6], Ronkainen [88] }\end{array}$ \\
\hline Revenue stability & & $\begin{array}{l}\text { Bertoni [26], Neely et al. [96], } \\
\text { Yang and Evans [87] }\end{array}$ \\
\hline \multicolumn{3}{|l|}{ Customer-related criteria } \\
\hline Access to new customer segments & & $\begin{array}{l}\text { Bertoni [26], Bruhn and Hadwich [79], Cooper } \\
\text { and de Brentani [76], Ellen MacArthur } \\
\text { Foundation [6] }\end{array}$ \\
\hline Customer acceptance & Quality concerns, lack of ownership & $\begin{array}{l}\text { Baines et al. [58], Carbonell-Foulquié et al. [89], } \\
\text { Govindan and Hasanagic [18], } \\
\text { Griffin and Page [90], Hart et al. [25], } \\
\text { Mont et al. [86], Rizos et al. [97], } \\
\text { van Weelden et al. [95] }\end{array}$ \\
\hline Customer satisfaction/loyalty & $\begin{array}{l}\text { Satisfaction of customer needs, } \\
\text { product quality, individualized } \\
\text { product offering }\end{array}$ & $\begin{array}{l}\text { Alamerew et al. [27], } \\
\text { Carbonell-Foulquié et al. [89], Dziallas and } \\
\text { Blind [22], Ellen MacArthur Foundation [6], } \\
\text { Griffin and Page [90], Hart et al. [25], Man-zini } \\
\text { and Vezzoli [85], Mont et al. [86], Tukker [46] }\end{array}$ \\
\hline Customer interaction/data collection & & $\begin{array}{l}\text { Bertoni [26], Ellen MacArthur Foundation [6,7], } \\
\text { Mont et al. [86], Tukker [46] }\end{array}$ \\
\hline \multicolumn{3}{|l|}{ Product-related criteria } \\
\hline Product life & & $\begin{array}{l}\text { Bakker et al. [98], Bocken et al. [57], Ellen } \\
\text { MacArthur Foundation [6], Yang and Evans [87] }\end{array}$ \\
\hline \multicolumn{3}{|l|}{ Differentiation-related criteria } \\
\hline Corporate image & & $\begin{array}{l}\text { Bruhn and Hadwich [79], Ellen MacArthur } \\
\text { Foundation [6], Ormazabal et al. [54] }\end{array}$ \\
\hline Differentiation advantage & $\begin{array}{l}\text { Unique selling proposition (USP), } \\
\text { differentiation }\end{array}$ & $\begin{array}{l}\text { Cooper and de Brentani [76], Ellen MacArthur } \\
\text { Foundation [6], Evanschitzky et al. [75], } \\
\text { Hart et al. [25], Martinsuo and Poskela [92], } \\
\text { Rochford [93], Ronkainen [88], Tukker [46], } \\
\text { Yang and Evans [87] }\end{array}$ \\
\hline $\begin{array}{l}\text { Innovative advantage/ } \\
\text { future potential }\end{array}$ & & $\begin{array}{l}\text { Ellen MacArthur Foundation [6], } \\
\text { Evanschitzky et al. [75], Mont et al. [86] }\end{array}$ \\
\hline \multicolumn{3}{|l|}{ Competitor-related criteria } \\
\hline Competitive advantage & & $\begin{array}{l}\text { Alamerew et al. [27], Ellen MacArthur } \\
\text { Foundation [7], Griffin and Page [90], Manzini } \\
\text { and Vezzoli [85], Martinsuo and Poskela [92] }\end{array}$ \\
\hline Risk of imitation/substitution & Reaction of competitors, patentability & $\begin{array}{l}\text { Bruhn and Hadwich [79], } \\
\text { Carbonell-Foulquié et al. [89], Cooper et al. [71], } \\
\text { Cooper and de Brentani [76] }\end{array}$ \\
\hline Pressure on prices and terms & & $\begin{array}{l}\text { Bruhn and Hadwich [79], Ellen MacArthur } \\
\text { Foundation [6] }\end{array}$ \\
\hline \multicolumn{3}{|l|}{ Employee-related criteria } \\
\hline Employee satisfaction & & $\begin{array}{l}\text { Dziallas and Blind [22], Ellen MacArthur } \\
\text { Foundation [6], Yang and Evans [87] }\end{array}$ \\
\hline
\end{tabular}


Table 1. Cont.

\begin{tabular}{|c|c|c|}
\hline Criterion & Examples & Sources (Example) \\
\hline \multicolumn{3}{|l|}{ Business risks } \\
\hline Cost and revenue risks & $\begin{array}{l}\text { Probability of commercial success, } \\
\text { warranties, resource price volatility }\end{array}$ & $\begin{array}{l}\text { Cooper et al. [71], de Jesus and Mendonça [47], } \\
\text { Ellen MacArthur Foundation [6], Linder and } \\
\text { Williander [91], Martinsuo and Poskela [92], } \\
\text { Mont et al. [86], Shahbazi et al. [50] }\end{array}$ \\
\hline Extent of damage in case of failure & & Expert-based criterion \\
\hline Other economic risks & Natural disasters & Ellen MacArthur Foundation [6], Mont et al. [86] \\
\hline \multicolumn{3}{|l|}{ Resource availability } \\
\hline Availability of raw materials & & $\begin{array}{l}\text { Ellen MacArthur Foundation [6], Mont et al. [86], } \\
\text { Tura et al. [49] }\end{array}$ \\
\hline Availability of know-how & & $\begin{array}{l}\text { Cooper and de Brentani [76], } \\
\text { Dziallas and Blind [22], Ellen MacArthur } \\
\text { Foundation [6], Shahbazi et al. [50], } \\
\text { Sharma et al. [99], Tukker [46] }\end{array}$ \\
\hline Availability of human resources & & Cooper et al. [71], Shahbazi et al. [50] \\
\hline $\begin{array}{l}\text { Availability of partnerships / } \\
\text { networks }\end{array}$ & Cooperations, retail & $\begin{array}{l}\text { Bertoni [26], Bruhn and Hadwich [79], Dziallas } \\
\text { and Blind [22], Ellen MacArthur } \\
\text { Foundation [6,7], Mont et al. [86], } \\
\text { Shahbazi et al. [50], Tura et al. [49] }\end{array}$ \\
\hline Availability of financing funds & & $\begin{array}{l}\text { Dziallas and Blind [22], Rizos et al. [97], } \\
\text { Shahbazi et al. [50] }\end{array}$ \\
\hline \multicolumn{3}{|l|}{ Cultural and strategic fit } \\
\hline Mindset/corporate culture & & $\begin{array}{l}\text { Dziallas and Blind [22], Evanschitzky et al. [75], } \\
\text { Kirchherr et al. [20], Pinheiro et al. [21], } \\
\text { Shahbazi et al. [50], Tukker [46] }\end{array}$ \\
\hline Extent of change & & Bocken et al. [57], Tukker [46] \\
\hline Strategic fit & Top-management support & $\begin{array}{l}\text { Bertoni [26], Carbonell-Foulquié et al. [89], } \\
\text { Cooper and de Brentani [76], Dziallas and } \\
\text { Blind [22], Evanschitzky et al. [75], Govindan } \\
\text { and Hasanagic [18], Martinsuo and Poskela [92], } \\
\text { Mont et al. [86], Shahbazi et al. [50], } \\
\text { Tura et al. [49] }\end{array}$ \\
\hline \multicolumn{3}{|l|}{ Implementation risks } \\
\hline Technical feasibility & & $\begin{array}{l}\text { Alamerew et al. [27], Cooper et al. [71], de Jesus } \\
\text { and Mendonça [47], Hart et al. [25], Martinsuo } \\
\text { and Poskela [92] }\end{array}$ \\
\hline Current/future legal situation & & $\begin{array}{l}\text { Alamerew et al. [27], Baines et al. [58], } \\
\text { Cooper et al. [71], de Jesus and Mendonça [47], } \\
\text { Dziallas and Blind [22], Masi et al. [51], } \\
\text { Mont et al. [86], Shahbazi et al. [50], } \\
\text { Tura et al. [49] }\end{array}$ \\
\hline
\end{tabular}

\section{Research Method}

This study is based on a qualitative, empirical research approach. It examines circular project selection in CE pioneer companies and chooses an interview study as research design. The sample (Table 2) consists of 18 experts from different countries in Europe and from the United States. Fourteen representatives from CE pioneer companies were interviewed one case each, along with four company-independent CE experts who contributed their experience with different companies. CE pioneer companies are firms that had introduced or were introducing a novel, game-changing, complex, or especially elaborated circular 
solution. The interviewed company representatives are the managers from these companies who were responsible for or deeply involved in the circular innovation process. CE experts are $C E$ consultants, politicians, researchers, and founders of CE non-profit organizations. They have closely collaborated with CE pioneer companies and are well informed about circular innovation processes in a variety of organizations. The sample includes a broad range of industries and circular solutions. Both large- and middle-sized companies are represented in the study from the automotive, electronics, apparel, household appliance, printing, concrete, tile, sanitary, tourism, and carpet industry. The intentional lack of industry specialization and the variety of analyzed circular solutions enables a broad applicability of the findings. The empirical data were previously used in an unpublished master thesis by one of the authors [100].

The interviews were concerned with 14 circular innovation projects that can be regarded as pioneer examples because of the game-changing or elaborated nature of the respective circular solution. They cover five business-to-consumer (B2C) and nine businessto-business (B2B) solutions, whereas some of the B2B solutions were eventually designed for end users. The discussed cases comprise both closed cycle solutions with technical and biological material cycles and systemic solutions with PSS and larger systemic solutions. The closed cycle solutions include, for example, cradle-to-cradle certified recycling, cascade use of tile materials across industries, the remanufacturing of household appliances, biodegradable products, or the extraction of biochemicals from wastewater. Systemic solutions include offers such as pay-per-service for lighting systems, sharing of household appliances, and connected mobility systems. Some companies combined both types of circular solutions, for example by providing leasing of carpets with a take-back system and following recycling activities. The 14 cases were supplemented with the experience of four independent CE experts that closely collaborated with a variety of additional CE pioneer companies.

The sample mostly entails circular solutions that were regarded as promising and successful by their companies. However, the majority of innovations faced problems on their way to implementation and, despite their success, also had negative impacts on different corporate objectives. These experiences were examined in research question 1. Both positive and negative effects of circular innovations are relevant for the project selection decision. Therefore, interview questions focused not only on the evaluation criteria that companies originally considered for the decision (ex ante) but also on criteria that proved important in retrospect, after implementation (ex post). To find knowledgeable key informants, purposeful sampling was employed [101]. A preliminary search in the CE literature, in conference programs, and on CE websites e.g., [6,102,103] identified suitable interview partners, who were contacted directly or via their company's press department. Additionally, snowball sampling [101] was applied. Thirty potential interview partners were approached, resulting in 18 confirmations. For all 14 company cases, the pioneer status of the projects was assessed by an independent CE expert, and the expertise of the interviewed managers was confirmed at the beginning of each interview.

As the interview type, systematizing expert interviews [104] were chosen. They were designed as semi-structured open interviews [105] with a partly standardized interview guideline that was adjusted to the individual interview situation. All interviews were conducted in June or July 2016, either personally or by telephone, and each lasted 45-60 min. The interviews were recorded and transcribed. The interview language was either English or German, with citations from German interviews being literally translated into English. All interview partners agreed to disclose their company, their position (at the time of the interview and/or relevant former position), and the type of circular innovation discussed in the interview. One test interview was conducted to ensure that questions and evaluation criteria were clearly understood $[25,106]$. 
Table 2. Overview of interview partners.

\begin{tabular}{|c|c|c|c|}
\hline Organization & Role of Interviewee & CE Experience of Company/Interviewee & Country \\
\hline EPEA GmbH & Founder, researcher & All fields of CE & Germany \\
\hline European Union & Former EU Commissioner for the Environment & All fields of CE & Belgium \\
\hline SYSTEMIQ & Founder, researcher & All fields of CE & Germany \\
\hline Philips & Project Manager CE & Pay-per-service offers & The Netherlands \\
\hline BMW Group & Head of Electric Vehicles & Connected mobility systems & Switzerland \\
\hline BMW Group & Former Project Manager of ParkNow & Service-based mobility solution with CE effects & Germany \\
\hline BMW Group & CEO DriveNow GmbH & Sharing economy & Germany \\
\hline BSH Hausgeräte GmbH & Manager Corporate Technology, Environment, Resources & Recycling, remanufacturing, biological cycle & Germany \\
\hline BSH Hausgeräte GmbH & CEO WeWash GmbH & Sharing economy, platform economy & Germany \\
\hline Desso & Former CEO & Leasing with recycling and biological cycle & The Netherlands \\
\hline Schiphol Group & $\begin{array}{l}\text { Program Coordinator Resources, Residuals, } \\
\text { Sustainability, Innovation }\end{array}$ & $\begin{array}{l}\text { Recycling, remanufacturing, reuse, extraction of } \\
\text { biochemicals from wastewater, zero-waste-plan }\end{array}$ & The Netherlands \\
\hline Shaw Industries Group Inc. & Vice President Sustainability and Environmental Affairs & Recycling, remanufacturing, reverse logistics & USA \\
\hline Van Houtum B.V. & Quality, Health, Safety, and Environment Officer & Recycling, circular water usage, biological cycle & The Netherlands \\
\hline Gugler & Product Manager & Recycling, non-toxic design, biological cycle & Austria \\
\hline Mosa & Manager Sustainability & $\begin{array}{l}\text { Design to last, cascade use across industries, } \\
\text { recycling, remanufacturing, biological cycle }\end{array}$ & The Netherlands \\
\hline Van Puijenbroek Textiel & Product Manager & Leasing combined with recycling, biological cycle & The Netherlands \\
\hline
\end{tabular}


The interview guideline was used in two different versions that are similarly structured but adapted to $\mathrm{CE}$ experts and company representatives, respectively. Both versions consist of four parts: introduction, context and process of project selection, evaluation criteria, and lessons and conclusions (Table 3). To examine how companies came to the decision to introduce circular solutions (RQ 2), interviewees were asked how their company became involved in CE activities, how the specific circular idea evolved, and how it was selected. To investigate evaluation criteria for circular innovation (RQ 1), first, questions referred to ex ante criteria, including the company's main argument for introducing a circular solution. The main argument was either determined from the context or through explicit inquiry. Second, questions aimed at ex post criteria that affected corporate objectives and could therefore have been important for the selection decision. To further stimulate considerations, a master list was given (personal interviews) or sent by email (telephone interviews) to the interviewees in the middle of the interview. It contained potentially relevant criteria for circular project selection (Table 1) and enabled the interviewees to name not only self-generated but also recognized criteria, based on the master list [61]. The criteria that required explanation were briefly discussed with the interview partners. To avoid a confirmation bias, the master list was only used as stimulation for further discussion and did not serve as checklist to be confirmed by the interviewees. It motivated the interviewees to qualitatively discuss the CE-relevance of further important but previously overlooked evaluation criteria.

Table 3. Interview guideline (core questions, company version).

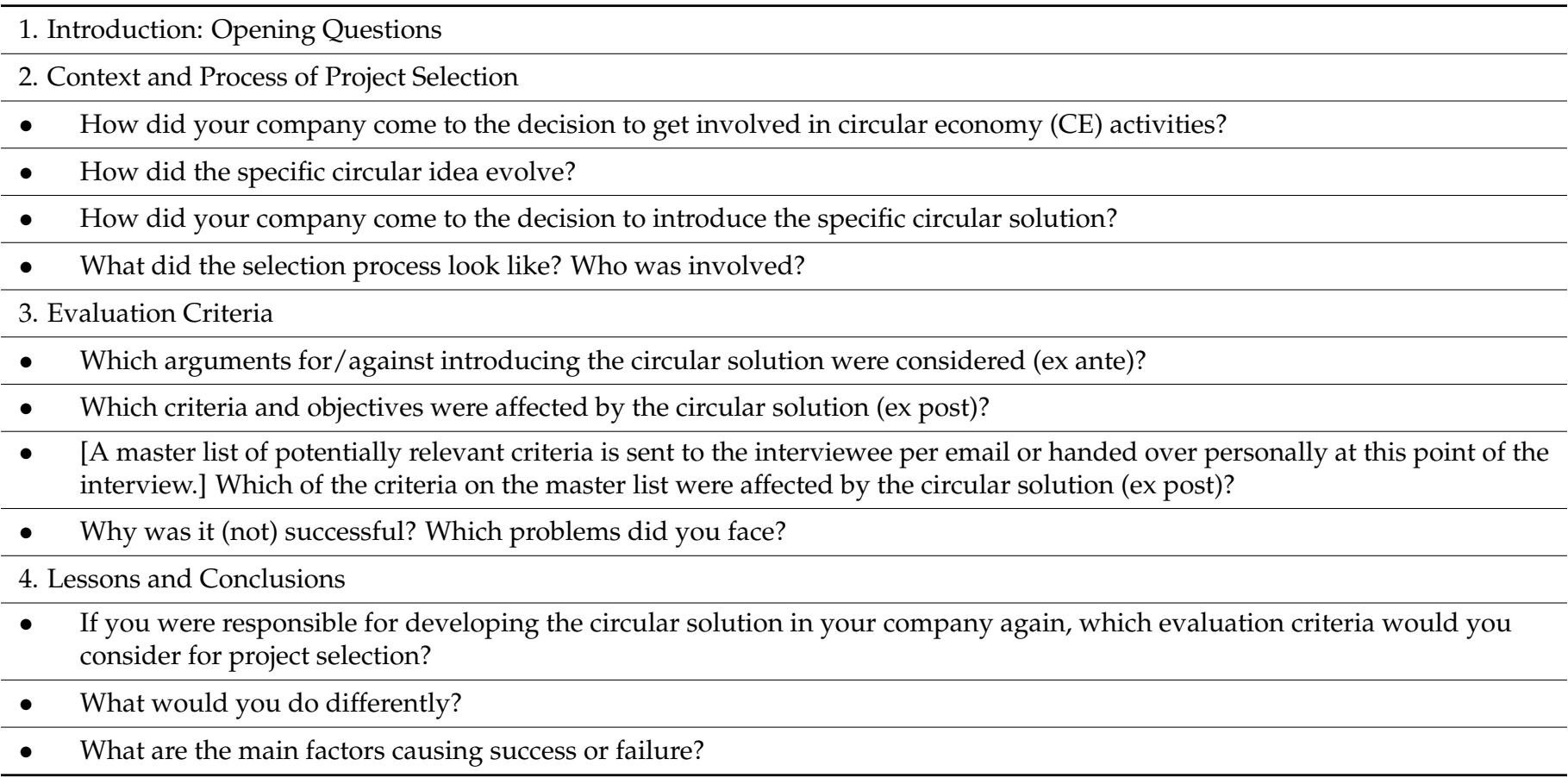

For the data analysis, a qualitative content analysis was performed [107]. For research question 1, most codes were developed deductively, based on the evaluation criteria listed in Table 1. Additional inductive codes were derived from the data [107]. To structure evaluation criteria into criteria groups and dimensions, deductive and inductive coding were combined [107]. Codes for research question 2 were mainly defined inductively. After the first round of coding, the data were checked a second time to ensure that all important findings were identified. To optimize the coding frame, it was discussed among the coauthors and in an informal interview with a strategy expert. Data analysis was performed in MAXQDA and Excel. The findings are presented in a qualitative style, supplemented with 
quantitative information on coding frequencies $[108,109]$ that indicate an initial tendency to affirm the relative importance of evaluation criteria but do not identify variance.

\section{Results}

In the following, findings on circular project selection in CE pioneer companies are presented. First, relevant criteria for the evaluation of circular innovations are analyzed (RQ 1). Second, the context and process of circular project selection are examined (RQ 2).

\subsection{Evaluation Criteria for Circular Project Selection}

Research question 1 focuses on criteria that CE pioneer companies regard as important to evaluate circular product and service innovations. In total, 276 codings were identified and assigned to 45 criteria. Of these codings, 160 were self-generated, and 116 were recognized on a master list. Furthermore, 85 codings referred to ex ante and 191 to ex post criteria. Thirty-two criteria were based on deductive coding, whereas 13 were inductively coded or extended. One criterion on the master list was not considered relevant in the interviews. After all criteria were coded, they were structured into a criteria framework with 12 criteria groups and two dimensions. In the following sections, the structure of the criteria framework is explained, and the relevance of coded criteria for the context of a CE is discussed in detail distinguishing between closed cycle and systemic solutions.

\subsubsection{Structure of the Criteria Framework}

The criteria framework clusters evaluation criteria for circular project selection thematically into 12 criteria groups and two dimensions. In the innovation literature, one of the key criteria groups is financial performance, reflecting profitability from a shareholder perspective [76]. This study divides financial performance into cost-related and revenue-related criteria to be able to analyze revenue and cost effects separately. The latter play an important role in the CE literature [5,57]. Revenue-related criteria focus on values that are direct prerequisites for sales calculations. Various other criteria groups have an indirect impact on revenues, especially customer-, product-, differentiation-, and competitorrelated criteria. Customer-related criteria are listed as distinct criteria group [79] due to the importance of the customer perspective for circular solutions, in particular PSS [6,46]. In accordance with innovation literature [75,76], three further aspects are added to the framework: Product-related criteria describe the characteristics of the product itself such as product life and quality. Differentiation- and competitor-related criteria are concerned with the product's external perception. The two criteria groups are strongly interconnected. However, differentiation-related criteria refer mainly to the market/customer view of the product, whereas competitor-related criteria deal with the effects on the competitive situation, including the revenue and cost side.

Due to their high relevance for a company's performance [110,111], the perspective of employees is regarded in its own criteria group (employee-related criteria). Furthermore, circular solutions can create strategic effects, a criteria group that was coded inductively. This group includes the development of know-how, a cross-sector dialogue, and value added for stakeholders, especially society. CE and sustainability research often emphasizes that the CE serves society with a positive environmental impact [112]. This aspect is not explicitly part of the framework. Instead, the underlying reasons for environmentally friendly behavior are covered. Some firms pursue an environmental agenda by conviction or aim for value added for stakeholders. Others do it to improve their own and customers' corporate image, to achieve a coherence of sales story and a differentiation advantage, or to increase employee and customer satisfaction. Therefore, environmental goals are not represented as such but, depending on the company's motivation, are reflected in other criteria. The potential risks of circular solutions have been divided into business and implementation risks [71]. Business risks include cost and revenue risks but also the extent of damage in case of failure. In contrast, implementation risks affect the implementation success and refer to technical feasibility and the legal situation, influenced by the stakeholder government. The necessity of certain 
resources, for example raw materials, know-how, or partnerships [22], is comprised by the criteria group resource availability. Furthermore, not only cultural and strategic topics but also leadership commitment can influence CE implementation, as is expressed in the criteria group cultural and strategic fit [22,75].

These 12 criteria groups follow two main directions. Either they influence company performance or are prerequisites for the successful implementation of circular solutions. Therefore, the criteria groups were structured into the two dimensions performance and ease of implementation, combining the diagrams market/concept attractiveness vs. ease of implementation and market/concept attractiveness vs. financial attractiveness, suggested by Cooper et al. [80]. The dimension performance bundles criteria that influence corporate success and product performance after market launch. The dimension ease of implementation refers to factors that affect the implementation success of product and service ideas, assessing how easily a circular innovation can be led to market launch. Table 4 shows the structure of the criteria framework and provides CE-specific details for individual criteria, based on the empirical findings of this study. New and extended criteria resulting from inductive coding are highlighted. In the following two sections, individual criteria and their CE implications are explained in depth along the structure of this framework. Where applicable, findings distinguish closed cycle and systemic solutions.

Table 4. Evaluation criteria for circular innovation (based on empirical results).

\begin{tabular}{|c|c|c|c|c|}
\hline Dimension & Criteria Group & Criterion & $\begin{array}{l}\text { Circular Economy (CE) } \\
\text { Implications (Example) }\end{array}$ & Frequency \\
\hline \multirow{16}{*}{ Performance } & \multirow{4}{*}{ Cost-related criteria } & Operating costs & $\begin{array}{l}\text { Lower raw material and energy costs; shorter } \\
\text { production time; more expensive } \\
\text { manufacturing techniques; increased costs in } \\
\text { marketing and sales }\end{array}$ & 12 \\
\hline & & Investment costs & $\begin{array}{l}\text { For R\&D, new machinery, and CE } \\
\text { certifications }\end{array}$ & 7 \\
\hline & & Financing costs/payback period & Due to CE long-term benefits & 5 \\
\hline & & Special cost effects & e.g., subsidies & 1 \\
\hline & \multirow{5}{*}{$\begin{array}{l}\text { Revenue-related } \\
\text { criteria }\end{array}$} & Pricing/willingness to pay & $\begin{array}{l}\text { Pricing for circular products higher; } \\
\text { willingness to pay for innovative, sustainable } \\
\text { features, time saving, or adventure; no great } \\
\text { price difference accepted by the customer }\end{array}$ & 9 \\
\hline & & Sales potential/market share & $\begin{array}{l}\text { Gaining market share from competitors; } \\
\text { winning large clients }\end{array}$ & 7 \\
\hline & & Revenue effects on other products & $\begin{array}{l}\text { Cannibalization; cross-selling of linear } \\
\text { products to new customers }\end{array}$ & 5 \\
\hline & & Market volume/market growth & To be examined & 4 \\
\hline & & Revenue stability & Increased for product-service systems (PSS) & 4 \\
\hline & \multirow{7}{*}{$\begin{array}{l}\text { Customer-related } \\
\text { criteria }\end{array}$} & Access to new customer segments & $\begin{array}{l}\text { Attracting new customers with PSS or second } \\
\text { hand offers; new customers as example to } \\
\text { convince others }\end{array}$ & 11 \\
\hline & & $\begin{array}{l}\text { Customer interaction/data } \\
\text { collection }\end{array}$ & $\begin{array}{l}\text { More active customer dialogue in systemic } \\
\text { solutions; digitalization enabling collection of } \\
\text { customer data such as user profiles }\end{array}$ & 11 \\
\hline & & Customer satisfaction/loyalty & $\begin{array}{l}\text { Increased through higher customer } \\
\text { interaction, long-term customer relationships, } \\
\text { more innovativeness, and stronger USPs }\end{array}$ & 10 \\
\hline & & Customer acceptance & $\begin{array}{l}\text { New way of thinking required for systemic } \\
\text { solutions; problems with acceptance of } \\
\text { closed cycle solutions }\end{array}$ & 9 \\
\hline & & Addressing customer needs ** & $\begin{array}{l}\text { Related to changing customer behavior due } \\
\text { to societal megatrends }\end{array}$ & 4 \\
\hline & & Individualized product offering ** & $\begin{array}{l}\text { Enabled by more customer interaction and } \\
\text { digitalization }\end{array}$ & 2 \\
\hline & & Corporate image of customer ${ }^{* *}$ & Improved, especially regarding sustainability & 1 \\
\hline
\end{tabular}


Table 4. Cont.

\begin{tabular}{|c|c|c|c|c|}
\hline Dimension & Criteria Group & Criterion & $\begin{array}{l}\text { Circular Economy (CE) } \\
\text { Implications (Example) }\end{array}$ & Frequency \\
\hline \multirow{17}{*}{ Performance } & \multirow{3}{*}{$\begin{array}{l}\text { Product-related } \\
\text { criteria }\end{array}$} & Product quality ** & $\begin{array}{l}\text { Higher, e.g., through added value, more } \\
\text { product safety }\end{array}$ & 3 \\
\hline & & Scalability ${ }^{* *}$ & Important to reduce costs & 2 \\
\hline & & Product life & Extended through closed cycle solutions & 2 \\
\hline & \multirow{4}{*}{$\begin{array}{l}\text { Differentiation- } \\
\text { related criteria }\end{array}$} & Differentiation advantage & $\begin{array}{l}\text { Improved market positioning through new } \\
\text { unique selling propositions (USPs) such as } \\
\text { ecological product features; CE-related USPs } \\
\text { partly not marketable }\end{array}$ & 13 \\
\hline & & $\begin{array}{l}\text { Innovative advantage/future } \\
\text { potential }\end{array}$ & $\begin{array}{l}\text { High innovative advantage; circular } \\
\text { solutions enabling long-term growth and } \\
\text { sustainable reaction to market depression }\end{array}$ & 13 \\
\hline & & Corporate image & $\begin{array}{l}\text { Improved image regarding innovation and } \\
\text { sustainability; positive impact on } \\
\text { brand equity }\end{array}$ & 12 \\
\hline & & Coherence of sales story ** & $\begin{array}{l}\text { Alleviating conflict in linear system that } \\
\text { more product sales have negative societal } \\
\text { and environmental impact }\end{array}$ & 3 \\
\hline & \multirow{3}{*}{$\begin{array}{l}\text { Competitor-related } \\
\text { criteria }\end{array}$} & Competitive advantage & $\begin{array}{l}\text { Revenue side, e.g., outpace competitors with } \\
\text { circular solutions; cost side, e.g., better } \\
\text { asset management }\end{array}$ & 13 \\
\hline & & Risk of imitation/substitution & $\begin{array}{l}\text { High for many non-patentable closed cycle } \\
\text { solutions and PSS; low for cradle-to-cradle } \\
\text { and larger systemic solutions }\end{array}$ & 10 \\
\hline & & Pressure on prices and terms & Alleviated by closed cycle solutions & 4 \\
\hline & $\begin{array}{l}\text { Employee-related } \\
\text { criteria }\end{array}$ & Employee satisfaction & $\begin{array}{l}\text { Increased: deeper meaning of work, } \\
\text { community feeling, higher identification with } \\
\text { company, improved employer image; } \\
\text { decreased: systemic solutions changing way } \\
\text { of working and self-conception }\end{array}$ & 7 \\
\hline & \multirow{3}{*}{ Strategic effects } & $\begin{array}{l}\text { Cross-sector and industry } \\
\text { dialogue }\end{array}$ & $\begin{array}{l}\text { Improved value chain and market dialogue; } \\
\text { legitimate industry dialogue regarding joint } \\
\text { product standards; increased cross-sector } \\
\text { dialogue, e.g., in CE networks }\end{array}$ & 4 \\
\hline & & Development of know-how ** & $\begin{array}{l}\text { Gained during innovation process, } \\
\text { advantage for entire firm }\end{array}$ & 2 \\
\hline & & Value added for stakeholders $* *$ & e.g., society & 1 \\
\hline & \multirow{3}{*}{ Business risks } & Cost and revenue risks & $\begin{array}{l}\text { Liability and warranty risk; resource price } \\
\text { volatility }\end{array}$ & 6 \\
\hline & & Extent of damage in case of failure & $\begin{array}{l}\text { Damage for overall company if circular } \\
\text { innovation fails }\end{array}$ & 3 \\
\hline & & Other economic risks & & 0 \\
\hline \multirow{6}{*}{$\begin{array}{l}\text { Ease of } \\
\text { implementation }\end{array}$} & \multirow{6}{*}{ Resource availability } & Partnerships/networks & $\begin{array}{l}\text { Collaboration with innovation ecosystem } \\
\text { often required; partner management } \\
\text { as challenge }\end{array}$ & 7 \\
\hline & & Know-how & e.g., service-related sales experience for PSS & 5 \\
\hline & & Raw materials & Relevant due to an expected resource scarcity & 3 \\
\hline & & $\begin{array}{l}\text { Access to customers and sales } \\
\text { channels ** }\end{array}$ & $\begin{array}{l}\text { Other contact persons required for systemic } \\
\text { solutions; partly different sales channels, } \\
\text { market access, and external organizational } \\
\text { structures needed }\end{array}$ & 2 \\
\hline & & Human resources & Shortage of qualified labor & 2 \\
\hline & & Financing funds & Access to cash and potential investors & 1 \\
\hline
\end{tabular}


Table 4. Cont.

\begin{tabular}{|c|c|c|c|c|}
\hline Dimension & Criteria Group & Criterion & $\begin{array}{l}\text { Circular Economy (CE) } \\
\text { Implications (Example) }\end{array}$ & Frequency \\
\hline \multirow{6}{*}{$\begin{array}{l}\text { Ease of } \\
\text { implementation }\end{array}$} & \multirow{4}{*}{$\begin{array}{l}\text { Cultural and } \\
\text { strategic fit }\end{array}$} & Mindset/corporate culture & $\begin{array}{l}\text { Support for a CE as crucial success factor; } \\
\text { partly venturing culture required; } \\
\text { cannibalizing business models leading to } \\
\text { cultural change; circular thinking in decision } \\
\text { making of middle management necessary }\end{array}$ & 14 \\
\hline & & Strategic fit/conviction * & $\begin{array}{l}\text { Integrating sustainability and CE goals in } \\
\text { corporate strategy; conviction of the CE }\end{array}$ & 12 \\
\hline & & Top-management commitment $* *$ & $\begin{array}{l}\text { Required due to major changes in business } \\
\text { model, organization, and corporate culture }\end{array}$ & 10 \\
\hline & & Extent of change/complexity * & $\begin{array}{l}\text { Often great changes needed, e.g., in } \\
\text { organizational structure, accounting } \\
\text { practices, bonus structures }\end{array}$ & 6 \\
\hline & \multirow[t]{2}{*}{ Implementation risks } & Current/future legal situation & $\begin{array}{l}\text { Partly in favor of a CE, e.g., Green Deal in } \\
\text { EU; future legislation potentially threatening } \\
\text { linear business models; partly hindering a } \\
\text { CE, e.g., market restrictions for refurbished } \\
\text { products in other countries or regulations for } \\
\text { data security and liability }\end{array}$ & 9 \\
\hline & & Technical feasibility & $\begin{array}{l}\text { e.g., changed chemical formulation, reduced } \\
\text { compatibility with previously used materials, } \\
\text { problems with replication of former product } \\
\text { features }\end{array}$ & 5 \\
\hline Sum & & & & 276 \\
\hline
\end{tabular}

Note: Multiple codings per interview and criterion counted as one. ${ }^{*}$ Extended criterion, ${ }^{* *}$ New criterion.

\subsubsection{Criteria of the Dimension Performance}

The first criteria group of the dimension performance is cost-related criteria. In this group, four criteria were determined by the interviewees which are all related to closed cycle solutions. First, closed cycle innovations have an effect on operating costs. They can reduce raw material costs through recycling, remanufacturing, or reuse of products and machines. This cost advantage is particularly valuable in the light of rising resource prices. Production costs can be decreased due to more energy efficiency and shorter production times, whereas a change of manufacturing techniques might create negative or positive cost effects. When circular products are sold at higher prices, marketing and sales efforts require intensification and more financial resources. Second, closed cycle solutions often imply high investment costs, mainly for R\&D activities, but also for the replacement of old machinery or upfront cradle-to-cradle certification. Third, various circular solutions face uncertainty regarding how long the payback period is and whether additional financing costs are necessary: "Now we have some large projects, but in these we will only see the impact in the far future. This causes difficulties because they will maybe pay off in 2050" (Interviewee 18). Fourth, in some cases, special cost effects such as subsidies can influence the selection decision.

The group revenue-related criteria includes five individual criteria. First, some circular solutions are more expensive than their linear equivalents, such that pricing and willingness to pay become important issues. Customers are usually willing to pay more when the product is innovative and sustainable or satisfies special customer needs, such as time saving or adventure. However, they tend not to accept a great price difference: "Most customers say they want sustainable, circular, recycled [circular products], but they don't want to pay too much. If it is $10 \%$ more expensive, the customer doesn't want to pay for it" (Interviewee 7). Second, an increase of sales potential/market share was observed as a positive impact of circular solutions. Various CE pioneer companies were successful in gaining market share from their competitors or in winning larger clients. Interviewee 14 reports that their "market share in Europe only doubled from 15 to 30\%". Third, revenue effects on other products could counteract the increase of market share when circular solutions cannibalize the core business. For example, reuse solutions, connected mobility, or PSS can reduce 
sales of established products. In contrast, circular solutions can positively affect the core business when they attract the attention of new customers who then consider additionally buying the company's core products. Fourth, market volume and market growth are important external factors for the long-term success of circular solutions. They therefore play a role for the evaluation of circular innovation projects. Finally, revenue stability might be enhanced, especially with the introduction of PSS.

A further criteria group is customer-related criteria. Circular solutions can provide access to new customer segments. This access is advantageous for industries with growth problems in their core business. Various circular solutions, for example PSS and secondhand offers, open up growth opportunities by attracting new customer groups. These new customers can then set an example to convince existing customers of the circular product. A further criterion that is mainly seen as argument for systemic solutions is a higher customer interaction that additionally enables data collection. In long-lasting contracts, customer dialogue becomes more active and, combined with digitalization, gives the company information about their clients, for example how long they work and how their user profiles appear. Based on these profiles, individualized product offerings can be provided, and these are adapted to a specific customer. Examples include individual offers for PSS or waste usage. Customer satisfaction and loyalty might be increased for circular solutions through increased customer interaction, long-term client relationships, a higher degree of innovation, and stronger unique selling propositions (USPs). In contrast, various experts regard customer acceptance of circular solutions as questionable. Many customers still have linear patterns of thought, whereas particularly systemic solutions require new ways of thinking: "The question is: how far is the customer already adapted to this pattern of thought? We talk about owning and using. To what extent is the customer ready for such services?" (Interviewee 1). Problems with customer acceptance can also affect closed cycle solutions such as recycling or remanufacturing. To increase acceptance of circular solutions among existing customers, references from new customers might be used. The criterion addressing customer needs refers mainly to megatrends in society and to changing customer behavior, which can create a demand for circular solutions: "Social megatrends like digitalization, urbanization, sharing economy, simplification-you want to be ready for them. This is important when customer needs are changing, as the change is negative for the core business" (Interviewee 4). Furthermore, circular solutions can improve the corporate image of the customer, especially regarding sustainability.

In the context of product-related criteria, the findings show that circularity can increase product quality, for example by creating added value or by enhancing the product safety of closed cycle solutions. Whereas some interviewees ranked quality higher than quantity, others attached more importance to scalability because, as Interviewee 3 said, "the tailor-made solution costs a lot of money". Therefore, he sees a main success factor in standardizing circular solutions "from the first customer contact until signing the contract". Furthermore, circularity can extend product life. This criterion might be regarded as a logical consequence of reuse and refurbishing solutions. However, it was explicitly mentioned as an advantage in the interviews and was, thus, listed as an individual criterion.

Differentiation-related criteria unite several aspects. First, they refer to a differentiation advantage that can be created by an improved market positioning and by providing USPs in a changing market situation. Differentiation may be achieved with systemic but also with closed cycle solutions, for example, when ecological product characteristics are promoted. However, a differentiation advantage for circular products is not necessarily a given, as observed by Interviewee 12: "All these aspects, except for durability, are not marketable toward the customer, which means that I cannot explain which extra benefits they have". Second, circular solutions can generate innovation advantage and future potential. Interviewee 15 regards the $\mathrm{CE}$ as "the only real chance of innovation". Circular solutions with future potential might enable long-term growth or a sustainable reaction to market depression. Third, corporate image can be improved when "a boring company becomes a hip company" (Interviewee 2) due to the transition toward a CE. Circular solutions often positively impact brand eq- 
uity and strengthen a firm's reputation in the field of sustainability. Fourth, the CE can give meaning to a coherent sales story. In a linear business model, the sales logic is often inconsistent because "companies want to boost their sales but have to admit that the product is connected with a burden for society" (Interviewee 6). The CE solves this conflict by proposing solutions in which more consumption does not necessarily have a negative impact on society and environment.

The group competitor-related criteria includes three individual criteria. First, competitive advantage can be created. This advantage can occur on the revenue side: "Obviously, our competitors had a lot of sustainability. First, we had a me-too-motivation. But when it came to cradle to cradle, I said: 'It is better for the world and will give me an enormous competitive advantage'" (Interviewee 14). Moreover, competitive advantage might be generated on the cost side, for example, through a smarter asset management. Second, the criterion risk of imitation/substitution concerns intellectual property, reactions of competitors, and substitution by other products. In the interviews, the focus rested mainly on the risk of imitation and on intellectual property. Imitation can be a threat especially for closed cycle solutions when they are not patentable. However, low-price manufacturers, for example in China, are less likely to copy complex cradle-to-cradle solutions than traditional products. For systemic solutions, imitability depends on the innovation. PSS might be copied quickly as, "principally, every manufacturer can do that nowadays" (Interviewee 8). Solutions such as connected mobility are more difficult to imitate because managing systems requires much knowledge that cannot be gained easily. The last criterion in this group is pressure on prices and terms that might be alleviated by closed cycle solutions.

Employee-related criteria comprise only one criterion. Employee satisfaction can be positively affected by circular solutions because they give the employees' work deeper meaning: "The employees are proud of themselves. Before, they were selling carpets, now they are saving the world" (Interviewee 15). Additionally, the CE can create a feeling of community, lead to closer identification with the company, and make the firm more attractive as an employer. However, employee satisfaction might also be negatively affected by a CE. Systemic solutions, in particular, can create unwelcome changes in the employees' ways of working and self-conception.

Some circular solutions have positive strategic effects for a company overall. These effects include the initiation of a cross-sector and industry dialogue, referring to a value chain dialogue, a market dialogue, a legitimate industry dialogue regarding joint product standards, or a dialogue across industries. This last might occur within existing CE networks such as the CE100 initiative by the Ellen MacArthur Foundation. For firms with international expansion plans specifically, collaboration or exchange with CE pioneer companies from different sectors can be valuable. Another strategic effect is the development of know-how and the expertise that are gained during the circular innovation process, but which eventually serve the whole company. Lastly, the CE can create value added for the company's stakeholders. If value creation is not restricted to the boundaries of the firm, advantages for stakeholders such as society might be an interesting benefit of circular solutions.

The last criteria group in the dimension performance is business risks. This group mainly relates to cost and revenue risks that influence product and company success on the market. For instance, liability and warranty risks or resource price volatility can be reduced by circular solutions. Moreover, business risks include the extent of damage in case of failure, as thoroughly discussed in various companies. Certain circular solutions require a change, for example in product design, that cannot be easily returned. Interviewee 12 reports an intense discussion of this topic in his company, because "if it goes wrong, this really is a problem". Therefore, it is important to evaluate already in the selection decision how large the damage to the overall company would be if the circular solution failed on the market. Other economic risks such as natural disasters were not regarded as relevant by any of the interviewees. 


\subsubsection{Criteria of the Dimension Ease of Implementation}

In the dimension ease of implementation, the first criteria group, resource availability, is important in several respects. The availability of specific know-how can be a prerequisite for the successful implementation of circular solutions. One example is the service-related sales experience needed for the development of PSS. If important know-how is missing, the availability of networks and partnerships becomes a significant success factor. External experts such as recycling specialists but also the whole innovation ecosystem can add crucial knowledge to the company. In some cases, managing the partner network is challenging, for example when suppliers have to change their product range or when retail has to accept a new circular product. The process to convince external partners of circular solutions can be tedious and time-consuming. Moreover, access to the customer and to suitable sales channels is necessary. This access can be problematic when contact persons in B2B firms change through the introduction of systemic solutions. Whereas product sales are usually negotiated with the customer's sourcing department, PSS can require additional contacts in finance and operations. Some circular solutions also lead to a change of sales channels and market access such that the company must establish new external organizational structures. Further aspects of this criteria group include the availability of raw materials despite expected future resource scarcity and the availability of human resources, as related to the shortage of qualified labor. The availability of financing funds describes the access to cash and to potential investors.

Cultural and strategic fit also influences the implementation of circular innovations. The criterion mindset/corporate culture takes the perspective of employees and evaluates how favorable their mindset is toward a CE. The cultural change can be huge, for example, when cannibalizing business models are implemented that require a venturing culture. Additionally, the mindset of middle management might have to change to integrate the long-term logic in their decision making or to adapt organizational structures. Mindset and culture can fuel circular innovations if supportive patterns of thought are already prevalent in the company, but they can also hinder CE implementation if cultural discrepancies are too wide. In this context, strategic fit is crucial. To successfully implement circular innovations, companies must integrate sustainability and CE goals into their corporate strategy. In the majority of $\mathrm{CE}$ pioneer companies, the $\mathrm{CE}$ matched their corporate values and was aligned with their strategic orientation. Various companies, especially middle-sized firms, decided to introduce circular solutions due to strong convictions. They believed in the CE and wanted to support human health and the environment. In some companies, this conviction was independent of further ulterior motives and established a strong motivation on its own: "We want to make the world a little bit better and want to have a positive impact on the environment" (Interviewee 7). Interviewee 14 displays a similar attitude: "But I said: 'This is my focus, cradle to cradle, this is what I want.' I did it because I believed in it". To make sure that conviction was not only named as argument for the purpose of green washing due to an interview bias, the interviewer always probed for underlying motivations and only accepted conviction as distinct criterion if the outcome of the further questions confirmed the statement of the interviewees.

Corresponding with the strategic orientation, top-management commitment is an essential success factor for circular innovation because the company might have to deal with major changes in business model, organization, and corporate culture. In many firms, the CEOs lead the way toward a CE: "The leadership of the company has to believe in it. If the leadership recognizes the benefits and wants to change the world for the better, then it works" (Interviewee 14). In particular, the mentioned organizational changes inspired various companies to regard the criterion extent of change/complexity in their selection decision. One required change can relate to accounting practices that have to switch from product sales to PSS contracts. Another example is bonus structures that have to be adapted because they are focused exclusively on cash flow and would thus hinder the implementation of a CE. In certain cases, it might be necessary to place circular solutions in a separate organizational 
unit or subsidiary to counteract cannibalization effects and cultural discrepancies in the core business.

The final criteria group in the dimension ease of implementation is implementation risks. First, these risks constitute the current and future legal situation that influences the success of circular solutions. CE-friendly legislation such as the Green Deal in the EU can facilitate the implementation of circular products, whereas traditional business models might be substantially threatened: "I claim that in three to eight years a product that is not in line with the CE cannot be sold anymore because of the changed legal situation" (Interviewee 12). In contrast, circular solutions can also be affected negatively by legislation, for example when strong regulations in other countries restrict the market for refurbished products. Laws regarding data security and liability can also create problems. Second, technical feasibility is a critical success factor for closed cycle solutions. Some innovations require a change of chemical formulation or impede compatibility with previously applied materials. To maintain product quality, it can be a great challenge to replicate, for example, the exact color of a linear product.

\subsubsection{Summarizing Analysis of Evaluation Criteria}

The previous sections have presented a variety of evaluation criteria and their CEspecific implications for circular project selection. A summarizing analysis shows that the CE-specific nature of the proposed criteria is not reflected in the criteria themselves but shows only one level deeper, in their particular focus and application. For instance, operating costs are constituent of profitability calculations for most innovations but, in circular project selection, refer mainly to reduced resource and energy costs as well as changed manufacturing techniques. Furthermore, the findings reveal that the majority of criteria can be relevant for closed cycle and systemic solutions, with certain exceptions. The criteria groups cost-related criteria and strategic effects as well as the criteria pressure on prices and terms, product quality, product life, and technical feasibility were mostly acknowledged in the context of closed cycle solutions. All other criteria were discussed for both types of circular solutions. However, they often had different CE-specific implications for closed cycle and systemic solutions, respectively. The summarizing analysis also shows that the proposed criteria framework includes qualitative and quantitative aspects. Whereas the dimension ease of implementation mostly consists of qualitative criteria, the dimension performance entails qualitative and quantitative metrics. Cost-related criteria, revenue-related criteria, and business risks are measured quantitatively. In contrast, differentiation-related criteria, employee-related criteria, and strategic effects rather refer to qualitative criteria. The remaining criteria groups of this dimension include qualitative and quantitative aspects. Various criteria, for example access to new customer segments, can be evaluated either qualitatively or quantitatively, depending on the company's preference.

The results of this study offer first indications regarding the relevance of criteria for circular project selection that can be deduced from the frequency of codings and from the main arguments considered in the selection decision. Individual criteria with the highest frequency are mindset/corporate culture, differentiation advantage, innovative advantage/future potential, and competitive advantage. On the level of criteria groups, customerand differentiation-related criteria, as well as cultural and strategic fit played the most important role. They are followed by revenue-, competitor-, and cost-related criteria, as well as resource availability. The allocation of main arguments shows a similar distribution and, thus, supports this prioritization. However, findings on the relevance of criteria for circular project selection can be regarded as only initial indications, as they lack a quantitative validation. Furthermore, the importance of criteria strongly depends on the specific project and evaluation context; thus, related conclusions are difficult to generalize.

\subsection{Context and Process of Circular Project Selection}

The following section examines how CE pioneer companies came to the decision to introduce circular solutions (RQ 2). The results are based on $14 \mathrm{CE}$ pioneer cases 
in companies, supplemented with the experience of four CE experts in the context of additional CE pioneer cases. This section is concerned with the context and process of circular project selection and investigates how the evaluation criteria presented in Section 4.1 were applied. Figure 1 gives an overview of a typical process leading to circular project selection. The starting point for circular innovation was often a pre-decision by top management in favor of the CE. In several companies, the CEO or owner encountered the topic $\mathrm{CE}$ in a conference, read a book, saw a documentary, or heard a speech of Professor Michael Braungart about cradle-to-cradle design. Further inspiration came from customers and legislation, especially from the European CE action plan. These impulses led to a framework decision by top management to introduce circular solutions: "The CE program is strongly supported by the CEO who cheers on the whole thing and raises the bar" (Interviewee 3). Other firms had already been active in the field of sustainability. In these cases, the sustainability department identified the $\mathrm{CE}$ in the course of trend scouting for new sustainable investment opportunities. In four companies, no pre-decision for sustainability or for the CE was taken, but the circular innovation was embedded in the context of corporate strategy development. All of these cases refer to stand-alone systemic solutions that are not combined with closed cycle solutions. For instance, larger systemic solutions, sharing, and pay-per-service offers were not officially defined as circular solutions but identified as new strategic ideas for the company.

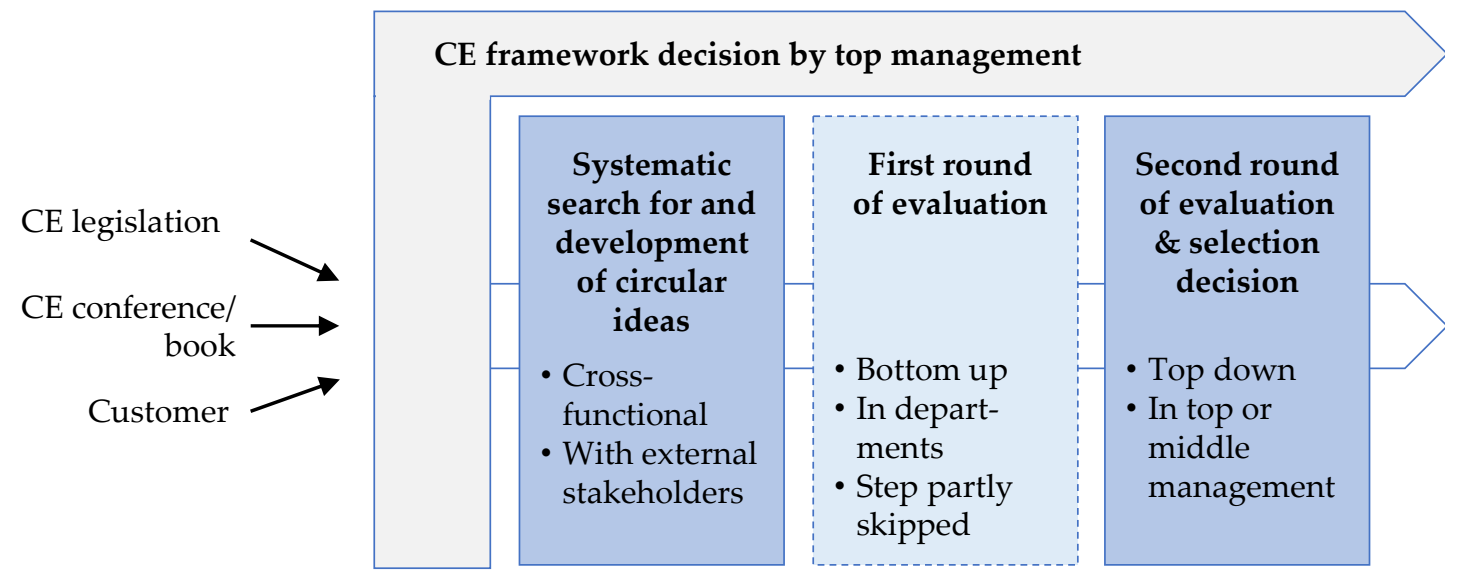

Figure 1. Process leading to circular project selection (example).

If a pre-decision for the $\mathrm{CE}$ was taken, companies searched explicitly for product and service ideas in the field of CE. Partly, they predefined the intended type of circular solution, for example recycling. Some companies structured their search along CE models such as the ReSOLVE framework [7], analyzed market trends, or identified ideas in a cradle-to-cradle certification process. Idea generation in the context of a cradle-to-cradle certification aimed at the development of closed cycle solutions with a certain purity of materials. It followed two steps: First, the company decided whether they should focus on the biological or the technical material cycle. Second, specific circular ideas were generated, based on the current product portfolio. When a cradle-to-cradle certification was pursued in small companies, the owner or CEO was personally in charge of the idea generation process. In larger companies, the R\&D or manufacturing department was responsible. Additionally, external consultants were involved, mostly Professor Michael Braungart and the EPEA GmbH. Suppliers were integrated to further develop the identified circular ideas.

Apart from cradle-to-cradle design, the search for circular ideas occasionally occurred in the sustainability department but was mostly performed in cross-functional teams. These teams included employees from departments such as business development, marketing, sales, R\&D, manufacturing, sourcing, sustainability, supply chain management, and controlling. Interviewee 12 was a member of a cross-functional team that was led by R\&D and comprised different business units: "First, we only looked at it from an RED perspective. 
Now, I would never do that again, but simultaneously consider the aspects of marketing potential and user experience". The majority of companies also involved external stakeholders, especially CE consulting firms, lead users, and cross-sector partners such as mechanical recyclers or sewage facilities. In one case the circular idea was refined in the context of a cross-industry dialogue with CE pioneer companies from the CE100 network, initiated by the Ellen MacArthur Foundation. Usually, idea generation was a one-time process. However, some companies introduced recurring idea workshops with external stakeholders or pursued an ongoing exchange in CE cross-industry networks to enhance their CE activities. The four companies that developed systemic solutions in the context of corporate strategy derived their ideas from an analysis of market trends, changing customer behavior, or new technologies. In part, their ideas were generated in a regular strategy process.

Once potentially interesting circular ideas had been developed, they were evaluated based on criteria. Thirty-one of the 45 evaluation criteria presented in Section 4.1 were applied ex ante and effectively influenced the selection decision in one or more companies. The other criteria were found to be relevant in retrospect but were not applied in a formal ex post evaluation. Therefore, empirical findings on the application of criteria refer only to ex ante evaluations in the context of circular project selection. The criteria used by the individual companies strongly differ. Frequently named ex ante criteria were innovation advantage/future potential, differentiation, and competitive advantage, but also investment costs and pricing/willingness to pay. The majority of evaluations included both qualitative and quantitative elements, usually with a larger number of qualitative criteria. The main argument for the introduction of the circular solution was almost exclusively qualitative and came preferably from the criteria groups differentiation-, customer-, and competitor-related criteria. The number of applied ex ante criteria ranges from two to eight, but the majority of companies evaluated three to five criteria. Usually, arguments for and against the circular solution were considered; however, in four cases only arguments in favor of the circular innovation were evaluated. Some of the companies relied on a general assessment of criteria, another part performed a detailed calculation based on an in-depth potential analysis, external studies, expert interviews, or market tests. Ideas for strategy-related systemic solutions and ideas for cradle-to-cradle solutions were typically compared to each other or to linear products. For example, cradle-to-cradle product ideas were assessed in relation to the current product portfolio and to other cradle-to-cradle options. In the other cases, circular ideas were mostly evaluated as single projects in absolute judgment, without the definition of minimum scores or thresholds. None of the interviewees reported the usage of a pre-defined criteria list to select relevant evaluation criteria. However, when companies embedded a circular innovation project in the context of ongoing strategic decision making, they applied their usual strategic approaches of potential and market analysis also for the circular project.

Regarding the evaluation process, three different procedures could be identified: First, one management level evaluated and selected the circular innovation. Decision makers came from top or middle management, for example executive board, CEO, owner, or Head of Development in a business unit. Second, a cross-functional commission of two management levels evaluated and decided to introduce the circular solution. Three companies put in charge a $\mathrm{CE}$ steering committee, referring to a board responsible for promoting and elaborating suggestions on the topic of $C E$ in the company. It was composed of members such as the $\mathrm{CEO}$, managers from sustainability, production, marketing/sales, and R\&D, as well as the heads of BUs. The management levels involved were mostly middle and top management. Third, the evaluation consisted of different steps. In about half of the interviewed companies, the circular innovation was first evaluated by a department such as sustainability, strategy, or R\&D. In a second step, it was advanced to top management or the head of a region for another evaluation and the final selection decision. In one company, the evaluation was distributed over three levels of hierarchy, beginning with the strategy department, followed by the Head of Innovation, and ending with the CEO. The number of final evaluators was often one person, but ranged from one to 13 , especially when a 
committee or the executive board was involved. In principle, all circular project selections were performed top down. However, the third option included bottom-up elements, as the first round of evaluation occurred in departments and was not completed by leadership.

\section{Discussion}

This study is concerned with project selection in circular innovation management. It examines evaluation criteria for the specific field of circular innovation (RQ 1) and investigates the context and process of circular project selection (RQ 2). The results show that different process steps lead to the selection of circular innovation projects. These steps include a CE framework decision, the development of circular ideas, and the evaluation of circular projects that can consist of more than one round. The circular innovation process is often initiated by top management who use their influence as important players $[59,60]$ and make framework decisions in favor of a CE. The literature found that top-management commitment is a crucial prerequisite for CE implementation $[6,18]$, such that a CE framework decision on the highest hierarchy level is a promising starting point for circular innovation. Systemic solutions partly have their origin in corporate strategy without any connection to CE strategies. Although this is a viable option by which to develop circular solutions, firms might miss important levers and sustainability opportunities in the company or the ecosystem. Therefore, it would be recommendable to relate all types of circular solutions to an overall CE strategy supported by top management.

With respect to the development of circular ideas, the most common approach is systematic, cross-functional, bottom-up ideation that involves external stakeholders. This practice accords with existing research that favors bottom-up idea generation [69] and suggests the involvement of different internal and external stakeholders to identify circular opportunities [16,21]. In contrast, the evaluation of circular projects is mostly performed top down, reflecting the structural influence of players such as top management on decision making $[15,59,60]$. Due to the importance of top-management support for CE implementation [18], a top-down approach can have great advantages, not only for a CE framework decision but also for the evaluation and selection of circular projects. However, external stakeholders and company culture have a similarly strong influence on the success of circular innovations $[6,20,21]$. Therefore, the integration of bottom-up elements in project evaluation would be advisable to increase the acceptance of circular solutions and develop a circular mindset in the workforce. Furthermore, bottom-up approaches with external stakeholders might utilize additional crowd wisdom, align CE initiatives with those of collaboration partners, and ensure the support of the company's ecosystem. To realize the benefits of both approaches, top-down and bottom-up elements should be combined. Employees and external stakeholders such as customers or suppliers could be involved in a first round of open evaluation [66], followed by a second round of top-management evaluation that takes the previous results as its basis. This approach considers the proposal of previous literature to perform the evaluation at different organizational levels and integrate external stakeholders to obtain a better assessment $[63,64]$. Alternatively, external stakeholders and employees from lower hierarchical levels of the company could become part of a CE steering committee in charge of the selection decision. As suggested by different authors $[31,63,64]$, a cross-functional team of evaluators is recommended to increase decision quality.

Circular project selection in CE pioneer companies is usually based on evaluation criteria. This practice is aligned with the notion of goal-based decision making $[23,24]$, which emphasizes the importance of decision strategies using multiple organizational goals as evaluation criteria. The results show that CE pioneer companies consider both qualitative and quantitative criteria in their selection decisions but tend more toward qualitative argumentation. The criteria are evaluated at varying levels of detail, with a similar emphasis on general assessments and in-depth calculations. The level of detail appropriate for an evaluation depends on the expertise and number of evaluators, but also on the selection of criteria and the availability of reliable data [22,72,73]. A specialized 
CE steering committee can calculate detailed profitability measures, whereas a consumer crowd is suitable for a more comprehensive and user-oriented evaluation [67]. Moreover, if criteria are strongly qualitative [22] or if forecasts are uncertain [6], the evaluation might better be based on a general assessment.

The findings reveal that companies typically evaluate between three and five criteria for circular project selection. According to the literature, this number of criteria is common when numerous ideas are assessed [67]. However, in this study, CE pioneer companies either made stand-alone decisions or compared their circular projects to only few other innovations. Therefore, they could have used a larger number of criteria [31,71] to ensure that all significant aspects of the evaluation would be covered. Since some companies did not discuss counter arguments for the introduction of a circular solution, the evaluations might have lacked essential metrics. To choose appropriate criteria and ensure no crucial arguments for the decision are overlooked, companies can use a comprehensive master list with potentially relevant criteria as a basis. As decision makers are usually unable to generate all important criteria for a decision by themselves, the usage of a criteria framework as master list can raise decision quality [61].

In this study, a criteria framework is developed for the context of circular innovation. It entails 45 criteria that proved relevant for circular innovation in CE pioneer companies. The framework includes not only ex ante criteria factually applied in the selection decision, but also ex post criteria that turned out to be important in retrospect. It structures individual criteria into criteria groups that describe main aspects of the evaluation. Comparing this structure with previous literature, it becomes clear that the common criteria groups for evaluation criteria described in innovation literature, namely product, financial performance, strategy, organization, network and economic environment $[22,25,75]$ are all covered in the new framework. However, the structure and composition of criteria groups have been adapted to the context of circular innovation to make important CE-relevant evaluation aspects such as cost vs. revenue or business risks vs. implementation risks directly comparable. One CE-specific criteria group, strategic effects, has been added based on the empirical data.

Criteria groups are further clustered into the dimensions ease of implementation and performance, inspired by Cooper et al. [80]. The understanding of performance in the framework does not reflect a mere shareholder view but takes a multiple stakeholder perspective [111], integrating criteria related to shareholders, customers, employees, crosssector companies, and stakeholders from the wider ecosystem. As interconnection with stakeholders is of particular importance for the transition toward a CE [18,19], the inclusion of multiple stakeholder perspectives is significant for circular project selection. Dziallas and Blind [22] structure their evaluation criteria for general innovations into a companyspecific dimension and a contextual dimension. However, this distinction leads to considerable overlaps and does not reflect the strong interconnectedness of a company with its external stakeholder system in a CE. To structure the newly developed criteria framework of this study, the dimensions performance and ease of implementation were selected because they display two directions that can easily be contrasted in circular innovation. Whereas an incremental circular solution might not have the best performance lever but is easy to implement, for a radical circular innovation such as connected mobility, the contrary can be true.

As circular innovations are also innovations as such, it is not surprising that the developed framework with a comprehensive criteria list does not only consist of new criteria but is strongly based on evaluation criteria from general innovation management. However, the framework adds value to the existing research in three respects: First, it filters the multitude of evaluation criteria in the innovation literature [22] as well as general arguments in CE research regarding their importance for circular project selection. Second, new CE-specific criteria are derived from the data, including corporate image of customer, coherence of sales story, cross-sector and industry dialogue, value added for stakeholders, and extent of damage in case of failure. Third, the findings detect CE-specific implications of all evaluation criteria. This aspect is the most important contribution of the criteria-related findings in 
this study as each criterion is discussed in detail from a circular innovation perspective, revealing possible implications of the criterion regarding different circular solutions.

For some criteria, the empirical results reveal CE implications that are new to the literature, because the criteria have been considered only in general innovation research thus far. Examples include sales potential/market share, addressing customer needs, scalability, risk of imitation/substitution, development of know-how, and access to customers and sales channels. For other criteria, the $\mathrm{CE}$ implications identified in this study and previous findings in $\mathrm{CE}$ research are congruent. Those criteria comprise revenue stability [87], corporate image [54], cost and revenue risks [50], availability of know-how [46], and availability of raw materials [6]. However, for the majority of criteria, the literature only discusses certain CE implications, whereas other considerations and more-detailed insights are missing. A first example is operating costs. The literature agrees on the ability of a CE to reduce raw material and energy costs $[6,49]$ but does not consider positive and negative effects on production costs or increased marketing and sales efforts. A second example is revenue effects on other products that CE research addresses only in terms of cannibalization [6] without identifying cross-selling effects on linear products. A third example is the pricing of circular solutions that the literature usually regards as lower than the pricing of linear alternatives [94]. In contrast, empirical findings refer to a higher pricing of some circular products.

Furthermore, the criteria-related findings of this study distinguish closed cycle and systemic solutions, where applicable. The CE literature does not provide such a distinction but partly refers CE-related aspects to a certain circular solution. The empirical results show that most criteria are important for both closed cycle and systemic solutions, but their specific CE implications differ, depending on the type of circular solution. However, some criteria are particularly relevant for closed cycle solutions, because they have a strong product focus. Examples include cost-related criteria, technical feasibility, product life, and product quality. The $\mathrm{CE}$ literature agrees with this assessment and clearly allocates the named criteria to closed cycle solutions $[5,6,57]$. More surprising is the result that inductively coded strategic effects such as cross-sector and industry dialogue or value added for stakeholders are also connected with closed cycle solutions in this study, a finding not previously reported in the literature. However, the reverse conclusion that systemic solutions do not lead to strategic effects would be premature. The high relevance of this criteria group for closed cycle solutions is rather related to the fact that the interviewees identified aspects such as CE networks and sustainable value creation for society as strategic effects. Since systemic solutions were derived mainly from corporate strategy without a specific CE focus, they were consequently not interconnected with CE networks, nor did they primarily focus on a sustainable value for stakeholders. To take full advantage of CE-related strategic effects, it is therefore recommended that not only closed cycle but also systemic innovations be embedded in a CE framework decision.

The proposed criteria framework represents a master list for circular project selection but does not provide a final criteria selection. Evaluation criteria should always be in line with corporate goals $[23,24]$ and with the company's prioritization in a certain decision [27]. Therefore, the selection of criteria must be individualized, depending on the project context. Nevertheless, the findings offer initial indications regarding the importance of criteria in the context of circular project selection. Particular significance can be attached to customerand differentiation-related criteria, as well as cultural and strategic fit. The relevance of cultural, strategic, and customer-related aspects is affirmed in the CE literature [20,21], whereas differentiation is regarded only as a side issue in previous studies $[6,46]$. Conversely, part of the $\mathrm{CE}$ research considers legislation and technological restraints as crucial influencing factors $[20,21,47]$ that do not play a leading role in this study. These discrepancies might be worth investigating in future research.

After defining suitable evaluation criteria for a specific innovation project, the question arises as to the form that the assessment of criteria should take. In the majority of CE pioneer companies, managers estimated the effect of circular solutions on evaluation criteria rather informally without defining minimum values or comparing the project to other 
innovations and existing products. This approach is simple but might lead to a subjective selection decision or the preferential treatment of top management's favorite projects. One option to ensure stronger objectivity is the application of a multi-criteria decision model $[26,27,113]$. Decision models can support the assessment of both quantitative and qualitative criteria. They enable comparison with other product ideas or existing products and are especially suitable when many criteria are to be evaluated. An example for a frequently used multi-criteria decision model is the weighted-sum model [113]. This model has the advantage that criteria are considered according to their relative importance for a specific selection decision. Additionally, it is highly transparent and thus facilitates the involvement of internal and external stakeholders in project selection. Criteria applied in the model should be aligned with the company's usual performance measures. Moreover, evaluation values must be normalized to enable different units of measurement, such as euros and percentages, to be compared [114]. Evaluation scores can be calculated for each criteria group such that the strengths and weaknesses of different innovation projects are easily weighed against each other.

The following propositions for the context of circular project selection can be derived from the findings of this study:

1. Top management should take a CE framework decision at the beginning of the innovation process.

2. For circular idea generation, cross-functional collaboration and the involvement of external stakeholders are advisable.

3. For the evaluation of circular projects, bottom-up and top-down approaches should be combined.

4. Evaluation criteria must be adapted to the specific project and the firm's corporate objectives. The criteria framework provided in this study can serve as a master list.

5. The appropriate number of criteria and the level of detail depend on the type of evaluation, the evaluators, and the availability of data.

6. The evaluation of circular innovation projects should be compared to other innovations and existing products, for example in a multi-criteria decision model.

This study makes a theoretical contribution by connecting the research streams CE and innovation. It investigates project selection in circular innovation management, a topic only scarcely addressed by existing literature. The study enhances CE knowledge by examining the context and process of circular project selection and by providing a CEspecific criteria framework. The practical contribution of this research addresses companies that plan to be engaged in circular innovation. It is significant for them to choose a suitable process and the right evaluation criteria for circular project selection. The future success of circular innovations is difficult to measure [16]; thus, an unsuitable selection of criteria might prevent the implementation of promising ideas. Furthermore, a CE-friendly mindset within the company and the involvement of key stakeholders are crucial for the successful implementation of circular innovations $[18,20,21]$. If a circular project is evaluated only by managers with a strict linear business understanding and not supported by the workforce and relevant external stakeholders, it might already be doomed to failure. This research shares the experience of $\mathrm{CE}$ pioneer companies, develops propositions for the process leading to circular project selection, and provides a criteria framework as a master list for the evaluation of circular innovations.

Three main limitations can be identified for this study. First, the qualitative research design restricts generalizability and an objective validation of the results. Although a broad variety of companies from diverse industries, of different size, and with B2B and B2C customers was interviewed, the sample was too small to achieve full generalizability. Future research should therefore investigate evaluation criteria and their CE-specific implications in a quantitative approach. Second, the broad sample led to a lack of detailed and specialized insights regarding certain sectors and types of companies such that it would be valuable to propose future qualitative research segmented according to industry, company size, and type of circular solution. Third, the sample comprises only CE pioneer examples 
that were finally implemented. This sampling decision could produce a bias regarding CE-friendly evaluation criteria. The inclusion of positive and negative ex post criteria mitigates this bias. Regardless, it might be of interest for future research to compare circular project selections with diverging decision outcomes and market success. Regarding decision processes in circular innovation projects, future research might distinguish between different industries, types of companies, and circular solutions in qualitative approaches. Moreover, topics such as stakeholder involvement in circular innovation management or the strategic implications of $\mathrm{CE}$ framework decisions could be more deeply investigated. Despite its limitations, the study is one of the first to discuss project selection in the context of circular innovation and thus contributes valuable insights to the $\mathrm{CE}$ literature.

\section{Conclusions}

This research focuses on two main objectives: First, it examines relevant evaluation criteria for circular innovation and structures them into a comprehensive framework. Second, it studies the context and process of circular project selection and investigates how the identified evaluation criteria are applied. A qualitative research approach enables deep insights into practices and assessments of CE pioneer companies to be collected. The sample was deliberately composed of diverse circular solutions, companies, and industries to ensure the validity of the findings for a broad range of circular innovations. The study makes a theoretical contribution by connecting the research streams of $\mathrm{CE}$ and innovation and by adding valuable knowledge on circular project selection to the $\mathrm{CE}$ literature. The practical contribution relates to companies on their way toward a CE. The findings may guide them on the process of circular project selection and on potentially relevant evaluation criteria. Considering the expected global resource scarcity and environmental problems, the $\mathrm{CE}$ can significantly impact the future of our economy. Investing now in game-changing circular solutions can make the difference between success and failure in the long term. Against this background, companies have a strong interest in being prepared for the new challenges of coming decades. If a CE is really "inevitable" [1], the courage of a company to rethink its own business model and question linear economic principles will be crucial. As Hermann Mulder, Chairman of the Global Reporting Initiative, says: "Nothing is impossible, particularly if it is inevitable" [6] (p. 84).

Author Contributions: A.E. is the corresponding author of this manuscript. As primary author she was in charge of conceptualizing the study, collecting and analyzing the interview data, writing the initial draft of the full paper as well as producing the figures and tables for the manuscript. J.F. supported the primary author in conceptualizing the study, supervising her in the whole process, and reviewing the paper internally. M.S. was involved in conceptualization and data collection. All authors have read and agreed to the published version of the manuscript.

Funding: This research received no external funding.

Acknowledgments: The authors would like to thank the Stiftung Familienunternehmen (Foundation for Family Businesses in Germany) for supporting this research in the context of a nonstipendiary scholarship.

Conflicts of Interest: The authors declare no conflict of interest.

\section{References}

1. Moore, D. Janez Potočnik: Resource Economy Not Only “Necessary" But “Inevitable”. Circular. 20 August 2013. Available online: https:/ / www.circularonline.co.uk/news/janez-potocnik-resource-economy-not-only-necessary-but-inevitable/ (accessed on 5 October 2021).

2. Andrews, D. The circular economy, design thinking and education for sustainability. Local Econ. 2015, 30, 305-315. [CrossRef]

3. United Nations. World Population Prospects 2019: Highlights. June 2019. Available online: https://population.un.org/wpp/ Publications/Files/WPP2019_10KeyFindings.pdf (accessed on 5 October 2021).

4. Lieder, M.; Rashid, A. Towards circular economy implementation: A comprehensive review in context of manufacturing industry. J. Clean. Prod. 2016, 115, 36-51. [CrossRef]

5. Ghisellini, P.; Cialani, C.; Ulgiati, S. A review on circular economy: The expected transition to a balanced interplay of environmental and economic systems. J. Clean. Prod. 2016, 114, 11-32. [CrossRef] 
6. Ellen MacArthur Foundation. Towards the Circular Economy: Economic and Business Rationale for an Accelerated Transition. 2013. Available online: http://www.ellenmacarthurfoundation.org/assets/downloads/publications/Ellen-MacArthurFoundation-Towards-the-Circular-Economy-vol.1.pdf (accessed on 5 October 2021).

7. Ellen MacArthur Foundation. Growth within: A Circular Economy Vision for a Competitive Europe. 2015. Available online: https:/ / www.ellenmacarthurfoundation.org/assets/downloads/publications/EllenMacArthurFoundation_GrowthWithin_July15.pdf (accessed on 5 October 2021).

8. Korhonen, J.; Honkasalo, A.; Seppälä, J. Circular economy: The concept and its limitations. Ecol. Econ. 2018, 143, 37-46. [CrossRef]

9. Geisendorf, S.; Pietrulla, F. The circular economy and circular economic concept-A literature analysis and redefinition. Thunderbird Int. Bus. Rev. 2018, 60, 771-782. [CrossRef]

10. Vasiljevic-Shikaleska, A.; Gjozinska, B.; Stojanovikj, M. The circular economy-A pathway to sustainable future. J. Sustain. Dev. 2017, 7, 13-30.

11. Bocken, N.M.P.; Strupeit, L.; Whalen, K.A.; Nußholz, J.L.K. A review and evaluation of circular business model innovation tools. Sustainability 2019, 11, 2210. [CrossRef]

12. Eppler, M.J.; Hoffmann, F. Does method matter? An experiment on collaborative business model idea generation in teams. Innovation 2012, 14, 388-403. [CrossRef]

13. Cooper, R.G. Stage-gate systems: A new tool for managing new products. Bus. Horiz. 1990, 33, 44-54. [CrossRef]

14. Cooper, R.G. New products: The factors that drive success. Int. Mark. Rev. 1994, 11, 60-76. [CrossRef]

15. Ocasio, W. Towards an attention-based view of the firm. Strateg. Manag. J. 1997, 18, 187-206. [CrossRef]

16. Hofmann, F.; Jaeger-Erben, M. Organizational transition management of circular business model innovations. Bus. Strategy Environ. 2020, 29, 2770-2788. [CrossRef]

17. Svensson, N.; Funck, E.K. Management control in circular economy. Exploring and theorizing the adaptation of management control to circular business models. J. Clean. Prod. 2019, 233, 390-398. [CrossRef]

18. Govindan, K.; Hasanagic, M. A systematic review on drivers, barriers, and practices towards circular economy: A supply chain perspective. Int. J. Prod. Res. 2018, 56, 278-311. [CrossRef]

19. Mendoza, J.M.F.; Sharmina, M.; Gallego-Schmid, A.; Heyes, G.; Azapagic, A. Integrating backcasting and eco-design for the circular economy: The BECE framework. J. Ind. Ecol. 2017, 21, 526-544. [CrossRef]

20. Kirchherr, J.; Piscicelli, L.; Bour, R.; Kostense-Smit, E.; Muller, J.; Huibrechtse-Truijens, A.; Hekkert, M. Barriers to the circular economy: Evidence from the European Union (EU). Ecol. Econ. 2018, 150, 264-272. [CrossRef]

21. Pinheiro, M.A.P.; Seles, B.M.R.P.; de Camargo Fiorini, P.; Jugend, D.; de Sousa Jabbour, A.B.L.; da Silva, H.M.R.; Latan, H. The role of new product development in underpinning the circular economy: A systematic review and integrative framework. Manag. Decis. 2019, 57, 840-862. [CrossRef]

22. Dziallas, M.; Blind, K. Innovation indicators throughout the innovation process: An extensive literature analysis. Technovation 2019, 80, 3-29. [CrossRef]

23. Cyert, R.M.; March, J.G. A Behavioral Theory of the Firm; Blackwell: Cambridge, MA, USA, 1963.

24. Simon, H.A. On the concept of organizational goal. Adm. Sci. Q. 1964, 9, 1-22. [CrossRef]

25. Hart, S.; Hultink, E.J.; Tzokas, N.; Commandeur, H.R. Industrial companies' evaluation criteria in new product development gates. J. Prod. Innov. Manag. 2003, 20, 22-36. [CrossRef]

26. Bertoni, M. Multi-criteria decision making for sustainability and value assessment in early PSS design. Sustainability 2019, 11, 1952. [CrossRef]

27. Alamerew, Y.A.; Kambanou, M.L.; Sakao, T.; Brissaud, D. A multi-criteria evaluation method of product-level circularity strategies. Sustainability 2020, 12, 5129. [CrossRef]

28. Kamp Albæk, J.; Shahbazi, S.; McAloone, T.C.; Pigosso, D.C.A. Circularity evaluation of alternative concepts during early product design and development. Sustainability 2020, 12, 9353. [CrossRef]

29. Rajagopalan, N.; Brancart, S.; de Regel, S.; Paduart, A.; de Temmerman, N.; Debacker, W. Multi-criteria decision analysis using life cycle assessment and life cycle costing in circular building design: A case study for wall partitioning systems in the circular retrofit lab. Sustainability 2021, 13, 5124. [CrossRef]

30. Füller, J.; Möslein, K.M.; Hutter, K.; Haller, J.B.A. Evaluation games-How to make the crowd your jury. In Informatik 2010: Service Science-Neue Perspektiven für Die Informatik: Beiträge der 40. Jahrestagung der Gesellschaft für Informatik e.V. (GI); Fähnrich, K.-P., Franczyk, B., Eds.; Köllen: Berlin, Germany, 2010; pp. 955-960.

31. Cooper, R.G. Perspective: The stage-gate idea-to-launch process-update, what's new, and nexgen systems. J. Prod. Innov. Manag. 2008, 25, 213-232. [CrossRef]

32. Boulding, K.E. The economics of the coming spaceship earth. In Environmental Quality in a Growing Economy; Jarrett, H., Ed.; John Hopkins University Press: Baltimore, MD, USA, 1966; pp. 3-14.

33. Pearce, D.W.; Turner, R.K. Economics of Natural Resources and the Environment; Johns Hopkins University Press: Baltimore, MD, USA, 1990.

34. Geissdoerfer, M.; Morioka, S.N.; de Carvalho, M.M.; Evans, S. Business models and supply chains for the circular economy. J. Clean. Prod. 2018, 190, 712-721. [CrossRef]

35. Lifset, R.; Graedel, T.E. Industrial ecology: Goals and definitions. In A Handbook of Industrial Ecology; Ayres, R.U., Ayres, L.W., Eds.; Edward Elgar Publishing: Cheltenham, UK, 2002; pp. 3-15. 
36. Lyle, J.T. Regenerative Design for Sustainable Development; Wiley Series in Sustainable Design; John Wiley \& Sons: New York, NY, USA, 1994.

37. Stahel, W.R. The Performance Economy; Palgrave Macmillan: Basingstoke, UK, 2006.

38. Benyus, J.M. Biomimicry: Innovation Inspired by Nature; William Morrow: New York, NY, USA, 1997.

39. Pauli, G.A. The Blue Economy: 10 Years, 100 Innovations, 100 Million Jobs; Paradigm Publications: Taos, NM, USA, 2010.

40. McDonough, W.; Braungart, M. Cradle to Cradle: Remaking the Way We Make Things; North Point Press: New York, NY, USA, 2002.

41. Kirchherr, J.; Reike, D.; Hekkert, M. Conceptualizing the circular economy: An analysis of 114 definitions. Resour. Conserv. Recycl. 2017, 127, 221-232. [CrossRef]

42. Korhonen, J.; Nuur, C.; Feldmann, A.; Birkie, S.E. Circular economy as an essentially contested concept. J. Clean. Prod. 2018, 175, 544-552. [CrossRef]

43. Ranta, V.; Aarikka-Stenroos, L.; Mäkinen, S.J. Creating value in the circular economy: A structured multiple-case analysis of business models. J. Clean. Prod. 2018, 201, 988-1000. [CrossRef]

44. Figge, F.; Thorpe, A.S. The symbiotic rebound effect in the circular economy. Ecol. Econ. 2019, 163, 61-69. [CrossRef]

45. Tukker, A. Eight types of product-service system: Eight ways to sustainability? Experiences from SusProNet. Bus. Strategy Environ. 2004, 13, 246-260. [CrossRef]

46. Tukker, A. Product services for a resource-efficient and circular economy-A review. J. Clean. Prod. 2015, 97, 76-91. [CrossRef]

47. De Jesus, A.; Mendonça, S. Lost in transition? Drivers and barriers in the eco-innovation road to the circular economy. Ecol. Econ. 2018, 145, 75-89. [CrossRef]

48. Su, B.; Heshmati, A.; Geng, Y.; Yu, X. A review of the circular economy in China: Moving from rhetoric to implementation. J. Clean. Prod. 2013, 42, 215-227. [CrossRef]

49. Tura, N.; Hanski, J.; Ahola, T.; Ståhle, M.; Piiparinen, S.; Valkokari, P. Unlocking circular business: A framework of barriers and drivers. J. Clean. Prod. 2019, 212, 90-98. [CrossRef]

50. Shahbazi, S.; Wiktorsson, M.; Kurdve, M.; Jönsson, C.; Bjelkemyr, M. Material efficiency in manufacturing: Swedish evidence on potential, barriers and strategies. J. Clean. Prod. 2016, 127, 438-450. [CrossRef]

51. Masi, D.; Kumar, V.; Garza-Reyes, J.A.; Godsell, J. Towards a more circular economy: Exploring the awareness, practices, and barriers from a focal firm perspective. Prod. Plan. Control 2018, 29, 539-550. [CrossRef]

52. Aloini, D.; Dulmin, R.; Mininno, V.; Stefanini, A.; Zerbino, P. Driving the transition to a circular economic model: A systematic review on drivers and critical success factors in circular economy. Sustainability 2020, 12, 10672. [CrossRef]

53. Dieckmann, E.; Sheldrick, L.; Tennant, M.; Myers, R.; Cheeseman, C. Analysis of barriers to transitioning from a linear to a circular economy for end of life materials: A case study for waste feathers. Sustainability 2020, 12, 1725. [CrossRef]

54. Ormazabal, M.; Prieto-Sandoval, V.; Puga-Leal, R.; Jaca, C. Circular economy in Spanish SMEs: Challenges and opportunities. J. Clean. Prod. 2018, 185, 157-167. [CrossRef]

55. Hidalgo-Carvajal, D.; Carrasco-Gallego, R.; Morales-Alonso, G. From goods to services and from linear to circular: The role of servitization's challenges and drivers in the shifting process. Sustainability 2021, 13, 4539. [CrossRef]

56. Brown, P.; Bocken, N.M.P.; Balkenende, R. Why do companies pursue collaborative circular oriented innovation? Sustainability 2019, 11, 635. [CrossRef]

57. Bocken, N.M.P.; de Pauw, I.; Bakker, C.A.; van der Grinten, B. Product design and business model strategies for a circular economy. J. Ind. Prod. Eng. 2016, 33, 308-320. [CrossRef]

58. Baines, T.S.; Lightfoot, H.W.; Evans, S.; Neely, A.; Greenough, R.; Peppard, J.; Roy, R.; Shehab, E.; Braganza, A.; Tiwari, A.; et al. State-of-the-art in product-service systems. Proc. Inst. Mech. Eng. J. Eng. Manuf. 2007, 221, 1543-1552. [CrossRef]

59. Hambrick, D.C.; Mason, P.A. Upper echelons: The organization as a reflection of its top managers. Acad. Manag. Rev. 1984, 9, 193-206. [CrossRef]

60. Hambrick, D.C. Upper echelons theory: An update. Acad. Manag. Rev. 2007, 32, 334-343. [CrossRef]

61. Bond, S.D.; Carlson, K.A.; Keeney, R.L. Generating objectives: Can decision makers articulate what they want? Manag. Sci. 2008, 54, 56-70. [CrossRef]

62. Onarheim, B.; Christensen, B.T. Distributed idea screening in stage-gate development processes. J. Eng. Des. 2012, 23, 660-673. [CrossRef]

63. Tidd, J.; Bessant, J.R. Managing Innovation: Integrating Technological, Market and Organizational Change, 7th ed.; John Wiley \& Sons: Chichester, UK, 2020.

64. Ulrich, K.T.; Eppinger, S.D.; Yang, M.C. Product Design and Development, 7th ed.; McGraw-Hill: New York, NY, USA, 2020.

65. Urban, G.L.; Hauser, J.R. Design and Marketing of New Products, 2nd ed.; Prentice-Hall: Engelwood Cliffs, NJ, USA, 1993.

66. Velamuri, V.K.; Schneckenberg, D.; Haller, J.B.A.; Moeslein, K.M. Open evaluation of new product concepts at the front end of innovation: Objectives and contingency factors. RED Manag. 2017, 47, 501-521. [CrossRef]

67. Haller, J.B.A.; Velamuri, V.K.; Schneckenberg, D.; Möslein, K.M. Exploring the design elements of open evaluation. J. Strategy Manag. 2017, 10, 40-65. [CrossRef]

68. Hacker, S.; von Ahn, L. Matchin: Eliciting user preferences with an online game. In Proceedings of the SIGCHI Conference on Human Factors in Computing Systems, Boston, MA, USA, 4-6 April 2009; pp. 1207-1216. [CrossRef]

69. Keum, D.D.; See, K.E. The influence of hierarchy on idea generation and selection in the innovation process. Organ. Sci. 2017, 28, 653-669. [CrossRef] 
70. Knudsen, T.; Levinthal, D.A. Two faces of search: Alternative generation and alternative evaluation. Organ. Sci. 2007, 18, 39-54. [CrossRef]

71. Cooper, R.G.; Edgett, S.J.; Kleinschmidt, E.J. Portfolio management for new product development: Results of an industry practices study. RED Manag. 2001, 31, 361-380. [CrossRef]

72. Kornish, L.J.; Hutchison-Krupat, J. Research on idea generation and selection: Implications for management of technology. Prod. Oper. Manag. 2017, 26, 633-651. [CrossRef]

73. Cooper, R.G. Managing Technology Development Projects. Res.-Technol. Manag. 2006, 49, 23-31. [CrossRef]

74. Hauschildt, J.; Schewe, G. Gatekeeper and process promotor: Key persons in agile and innovative organizations. Int. J. Agil. Manag. Syst. 2000, 2, 96-103. [CrossRef]

75. Evanschitzky, H.; Eisend, M.; Calantone, R.J.; Jiang, Y. Success factors of product innovation: An updated meta-analysis. J. Prod. Innov. Manag. 2012, 29, 21-37. [CrossRef]

76. Cooper, R.G.; de Brentani, U. Criteria for screening new industrial products. Ind. Mark. Manag. 1984, 13, 149-156. [CrossRef]

77. Dean, D.L.; Hender, J.; Rodgers, T.; Santanen, E. Identifying quality, novel, and creative ideas: Constructs and scales for idea evaluation. J. Assoc. Inf. Syst. 2006, 7, 646-699. [CrossRef]

78. Kudrowitz, B.M.; Wallace, D. Assessing the quality of ideas from prolific, early-stage product ideation. J. Eng. Des. 2013, 24, 120-139. [CrossRef]

79. Bruhn, M.; Hadwich, K. Produkt-und Servicemanagement: Konzepte-Prozesse-Methoden, 2nd ed.; Verlag Franz Vahlen: München, Germany, 2017.

80. Cooper, R.G.; Edgett, S.J.; Kleinschmidt, E.J. Portfolio Management for New Products; Perseus Publishing: Cambridge, MA, USA, 2001.

81. Clausen, J.; Fichter, K. The diffusion of environmental product and service innovations: Driving and inhibiting factors. Environ. Innov. Soc. Transit. 2019, 31, 64-95. [CrossRef]

82. Fichter, K.; Clausen, J. Diffusion dynamics of sustainable innovation-Insights on diffusion patterns based on the analysis of 100 sustainable product and service innovations. J. Innov. Manag. 2016, 4, 30-67. [CrossRef]

83. Horbach, J. Determinants of environmental innovation-New evidence from German panel data sources. Res. Policy 2008, 37, 163-173. [CrossRef]

84. Horbach, J.; Oltra, V.; Belin, J. Determinants and specificities of eco-innovations compared to other innovations-An econometric analysis for the French and German industry based on the Community Innovation Survey. Ind. Innov. 2013, 20, 523-543. [CrossRef]

85. Manzini, E.; Vezzoli, C. A strategic design approach to develop sustainable product service systems: Examples taken from the 'environmentally friendly innovation' Italian prize. J. Clean. Prod. 2003, 11, 851-857. [CrossRef]

86. Mont, O.; Plepys, A.; Whalen, K.A.; Nußholz, J.L.K. Business Model Innovation for a Circular Economy: Drivers and Barriers for the Swedish Industry - The Voice of REES Companies; Mistra: Stockholm, Sweden, 2017; Available online: https://lup.lub.lu.se/search/ ws / files/33914256/MISTRA_REES_Drivers_and_Barriers_Lund.pdf (accessed on 5 October 2021).

87. Yang, M.; Evans, S. Product-service system business model archetypes and sustainability. J. Clean. Prod. 2019, 220 , 1156-1166. [CrossRef]

88. Ronkainen, I.A. Criteria changes across product development stages. Ind. Mark. Manag. 1985, 14, 171-178. [CrossRef]

89. Carbonell-Foulquié, P.; Munuera-Alemán, J.L.; Rodríguez-Escudero, A.I. Criteria employed for go/no-go decisions when developing successful highly innovative products. Ind. Mark. Manag. 2004, 33, 307-316. [CrossRef]

90. Griffin, A.; Page, A.L. PDMA success measurement project: Recommended measures for product development success and failure. J. Prod. Innov. Manag. 1996, 13, 478-496. [CrossRef]

91. Linder, M.; Williander, M. Circular business model innovation: Inherent uncertainties. Bus. Strategy Environ. 2017, 26, 182-196. [CrossRef]

92. Martinsuo, M.; Poskela, J. Use of evaluation criteria and innovation performance in the front end of innovation. J. Prod. Innov. Manag. 2011, 28, 896-914. [CrossRef]

93. Rochford, L. Generating and screening new products ideas. Ind. Mark. Manag. 1991, 20, 287-296. [CrossRef]

94. Singhal, D.; Tripathy, S.; Jena, S.K. Acceptance of remanufactured products in the circular economy: An empirical study in India. Manag. Decis. 2019, 57, 953-970. [CrossRef]

95. Van Weelden, E.; Mugge, R.; Bakker, C.A. Paving the way towards circular consumption: Exploring consumer acceptance of refurbished mobile phones in the Dutch market. J. Clean. Prod. 2016, 113, 743-754. [CrossRef]

96. Neely, A.; Benedetinni, O.; Visnjic, I. The servitization of manufacturing: Further evidence. In Proceedings of the 18th European Operations Management Association Conference, Cambridge, UK, 3-6 July 2011.

97. Rizos, V.; Behrens, A.; van der Gaast, W.; Hofman, E.; Ioannou, A.; Kafyeke, T.; Flamos, A.; Rinaldi, R.; Papadelis, S.; HirschnitzGarbers, M.; et al. Implementation of circular economy business models by small and medium-sized enterprises (SMEs): Barriers and enablers. Sustainability 2016, 8, 1212. [CrossRef]

98. Bakker, C.A.; Wang, F.; Huisman, J.; den Hollander, M.C. Products that go round: Exploring product life extension through design. J. Clean. Prod. 2014, 69, 10-16. [CrossRef]

99. Sharma, Y.K.; Mangla, S.K.; Patil, P.P.; Liu, S. When challenges impede the process. Manag. Decis. 2019, 57, 995-1017. [CrossRef] 
100. Eisenreich, A. Entwicklung Eines Innovations-und Scoring-Modells für Circular Economy-Szenarien zur Anwendung in Unternehmen. Master's Thesis, Technische Universität München, München, Germany, 2016.

101. Patton, M.Q. Qualitative Research E Evaluation Methods, 4th ed.; SAGE Publications: Los Angeles, CA, USA, 2015.

102. C2C-Centre. Companies and Organizations: Frontrunners in Implementing and Adapting Cradle to Cradle. 2016. Available online: http:/ / www.c2c-centre.com/companies-and-organizations (accessed on 5 October 2021).

103. Metrovancouver. Zero Waste Conference 2014: Speakers. 16 September 2014. Available online: http:/ /www.Zwc.ca/archive/20 14/Pages/Speakers.aspx (accessed on 5 October 2021).

104. Bogner, A.; Menz, W. The theory-generating expert interview: Epistemological interest, forms of knowledge, interaction. In Interviewing Experts; Bogner, A., Littig, B., Menz, W., Eds.; Palgrave Macmillan: New York, NY, USA, 2009 ; pp. 43-80.

105. Myers, M.D. Qualitative Research in Business \& Management, 3rd ed.; SAGE Publications: Los Angeles, CA, USA, 2019.

106. Dziallas, M. How to evaluate innovative ideas and concepts at the front-end? J. Bus. Res. 2020, 110, 502-518. [CrossRef]

107. Schreier, M. Qualitative Content Analysis in Practice; SAGE Publications: Los Angeles, CA, USA, 2012.

108. Schreier, M. Qualitative content analysis. In The SAGE Handbook of Qualitative Data Analysis; Flick, U., Ed.; SAGE Publications: Los Angeles, CA, USA, 2014; pp. 170-183.

109. Saldaña, J. The Coding Manual for Qualitative Researchers, 3rd ed.; SAGE Publications: Los Angeles, CA, USA, 2016.

110. Clarkson, M.E. A stakeholder framework for analyzing and evaluating corporate social performance. Acad. Manag. Rev. 1995, 20, 92-117. [CrossRef]

111. Freeman, R.E.; Harrison, J.S.; Zyglidopoulos, S. Stakeholder Theory: Concepts and Strategies; Cambridge University Press: Cambridge, UK, 2018.

112. Geissdoerfer, M.; Savaget, P.; Bocken, N.M.P.; Hultink, E.J. The circular economy-A new sustainability paradigm? J. Clean. Prod. 2017, 143, 757-768. [CrossRef]

113. Triantaphyllou, E. Multi-Criteria Decision Making Methods: A Comparative Study; Springer: New York, NY, USA, 2000.

114. Rehman, S.; Khan, S.A. Multi-criteria wind turbine selection using weighted sum approach. Int. J. Adv. Comput. Sci. Appl. 2017, 8, 128-132. [CrossRef] 